\title{
26. CENOZOIC RADIOLARIANS FROM THE SOUTHWEST ATLANTIC, FALKLAND PLATEAU REGION, DEEP SEA DRILLING PROJECT LEG 71 ${ }^{1}$
}

\author{
Fred M. Weaver, ${ }^{2}$ Exxon Production Research Company, Houston, Texas
}

\section{INTRODUCTION}

Deep Sea Drilling Project Leg 71 occupied four sites and drilled six holes in the middle- to high-latitude regions of the southwest Atlantic Ocean. Sites 511 and 512 are located on the Falkland Plateau: 511 is at $51^{\circ}$ $00.28^{\prime} \mathrm{S}, 46^{\circ} 58.30^{\prime} \mathrm{W}(2589 \mathrm{~m}$ water depth) in the plateau basin province and 512 at $49^{\circ} 52.19^{\prime} \mathrm{S}, 40^{\circ}$ $50.71^{\prime} \mathrm{W}$ (1846 $\mathrm{m}$ water depth) on the northeastern margin of the Maurice Ewing Bank (Fig. 1). Sites $513\left(47^{\circ}\right.$ $34.99 \mathrm{~S}, 24^{\circ} 38.40^{\prime} \mathrm{W} ; 4383 \mathrm{~m}$ water depth) and $514\left(46^{\circ}\right.$ $02.76^{\prime}, 26^{\circ} 51.29^{\prime} \mathrm{W} ; 4318 \mathrm{~m}$ water depth) are positioned on the lower western flank of the Mid-Atlantic Ridge system. Hydraulic piston coring (HPC) was successfully used at Sites 512 and 514 . Sediments were recovered at all the other sites using conventional coring methods.

As has been the case with previous DSDP Legs into the subantarctic and antarctic regions, bad weather and ice conditions considerably affected or delayed sediment coring, and we were unable to remain at several of the sites for as long as we would have preferred. However, we were very successful in recovering some heretofore uncollected high-latitude sections of Pliocene to Eocene age. The most interesting and scientifically productive intervals include (1) a composite, essentially complete, early Miocene to late Eocene section in Holes 511 and 513A; (2) an excellent middle/late Miocene boundary and middle Eocene section in Hole 512; (3) a very good late Miocene section containing sediments from Magnetic Chronozones 9, 6, and 5 in Hole 513A, and (4) a Pliocene interval with a high sedimentation rate in Hole 514 near the modern position of the Polar Front Zone. Detailed studies of these sections and other DSDP holes in subantarctic and antarctic regions significantly increase our understanding of Cenozoic and Mesozoic high-latitude biostratigraphy and paleoceanographic history.

Radiolarians are generally well preserved, abundant, and diverse in all Cenozoic sediments recovered during Leg 71. In contrast, the Mesozoic section collected at Hole 511 contains only a few sporadic occurrences of radiolarians in Samples 511-23,CC, 511-56,CC, and 511$57, \mathrm{CC}$. Most specimens are poorly preserved or recrystallized. Sample 511-23,CC contains a Maestrichtian assemblage with Dictyomitra regina, D. lamellicostata, and Amphipyndax sp., whereas Samples 511-56,CC and

\footnotetext{
${ }^{1}$ Ludwig, w. J., Krasheninnikov, v. A., et al., Init. Repts. DSDP, 71: Washington (U.S. Govt. Printing Office).

2 Present address: Exxon U.S.A., Gulf/Atlantic Division, Houston, Texas.
}

511-57,CC yield specimens of the lower Albian to upper Aptian species Thanarla conica and Archaeodictyomitra vulgaris.

\section{BIOSTRATIGRAPHIC FRAMEWORK}

The antarctic/subantarctic radiolarian zonation proposed by Chen (1975) is used, with several modifications, to zone Neogene sediments recovered during Leg 71. Since a radiolarian zonation for the Paleogene has not been established in high latitudes and because most Paleogene species identified in Leg 71 samples are endemic to the area, Eocene and Oligocene age determinations are based on the occurrence of secondary marker species whose ranges are established in low-latitude regions (Riedel and Sanfilippo, 1978).

As part of the investigation of Leg 71 radiolarians, my data are supported by detailed radiolarian documentation from other DSDP sites and many Eltanin and Islas Orcadas piston cores from the Southern Ocean region. These include DSDP Leg 29, Hole 278; Leg 28, Hole 266; Leg 36, Hole 329; Eltanin Cores 16-4, 36-33, 50-28, 38-8, 14-8, 43-2, 13-17, and 34-5; and Islas Orcadas (IO) Cores 7-49, 7-54, 7-48, 7-55, 7-2, 16-108, and 16-109. Paleomagnetic data are available on these piston cores. Radiolarians in Holes 278, 266, and all Eltanin cores were documented in an earlier study (Weaver, 1976a). Detailed data from these cores will be published separately by Ciesielski and Weaver.

Piston cores provide a more complete record of early Pliocene radiolarian distribution throughout the Gilbert Magnetic Chronozone, thus allowing a high-resolution subdivision of Chen's (1975) Helotholus vema Zone into the Desmospyris spongiosa, Triceraspyris corona$t a$, and Stichocorys peregrina zones. The D. spongiosa Zone is defined from the first occurrence of $D$. spongios $a$ to the evolutionary transition from $H$. praevema to $H$. vema ( $\sim 4.25$ to $4.0-3.95 \mathrm{Ma})$. The $T$. coronata Zone is defined from the last occurrence of $S$. peregrina to the first occurrence of $D$. spongiosa ( $\sim 4.5$ to $4.25 \mathrm{Ma})$. Finally, the $S$. peregrina Zone is defined by the total range of $S$. peregrina ( $\sim 6.0$ to $4.5 \mathrm{Ma})$. The base of the $S$. peregrina Zone is not directly correlated to paleomagnetic stratigraphy. However, in Hole 513A, the first occurrence of $S$. peregrina coincides with the first appearance of the diatom Thalassiosira praeconvexa, which in low latitudes correlates with the upper reversed interval of Chronozone 6 (Haq et al., 1980).

Radiolarian data from DSDP Leg 29, Hole 278, require a modification of Chen's (1975) late to middle Miocene zones. In Hole 278, Antarctissa conradae ranges below the first occurrence of Actinomma tanyacan- 


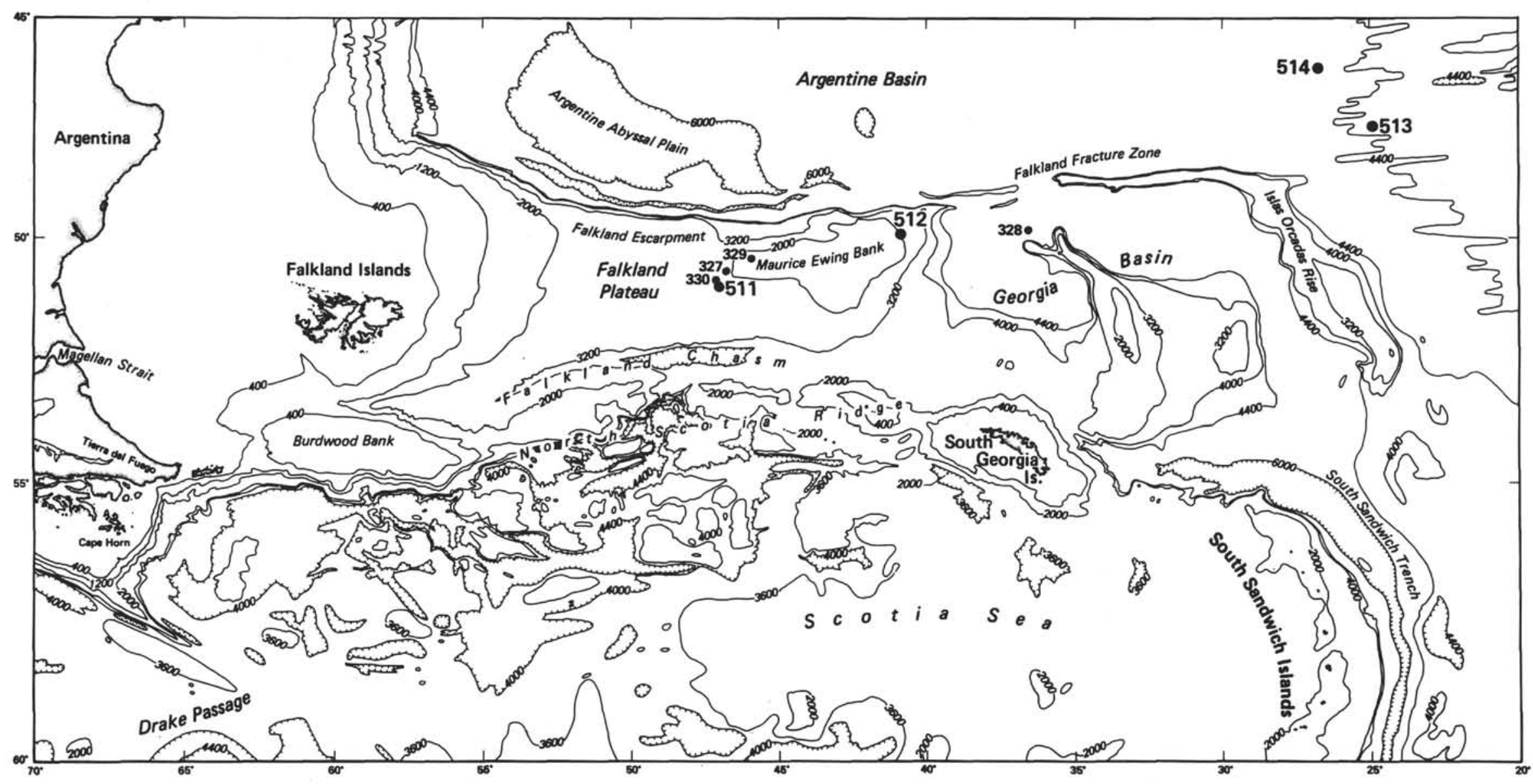

Figure 1. Location of Leg 71 sites. 
tha (Petrushevskaya, 1975; this study). Antarctissa conradae has a split range that brackets the middle/late Miocene boundary. Therefore, I redefine Chen's (1975) Actinomma tanyacantha Zone from the first occurrence of A. tanyacantha to the first occurrence of Theocalyptra bicornis spongothorax, thus eliminating the Antarctissa conradae Zone. The top of the Actinomma tanyacantha Zone correlates with upper Magnetic Chronozone 10 or possibly basal $9(\sim 10.5$ to $9.5 \mathrm{Ma})$ based upon data from Hole 512 and piston cores IO 7-55, $7-54,7-49$, and 7-48.

The $T$. bicornis spongothorax Zone of Chen (1975) is redefined from the first occurrence of $T$. bicornis spongothorax to the first occurrence of $S$. peregrina $(\sim 10.5-$ 9.5 to $6.0 \mathrm{Ma}$ ). Piston core data from IO 7-49 shows that the upper range of $T$. bicornis spongothorax extends at least into Magnetic Chronozone 8 at $\sim 8.3 \mathrm{Ma}$. As far as can be discerned, no upper Chronozone 8 to middle Chronozone 6 sections have been collected in piston cores from the Southern Ocean. This major gap in the sedimentary record spans the interval between 6.0 and $8.3 \mathrm{Ma}$.

\section{Biostratigraphically Important Datums}

Radiolarian stratigraphy in Neogene sediments from Leg 71 Holes 512, 513A, and 514 and the piston cores previously mentioned permits calibration of several Pliocene to middle Miocene datums to the geologic and paleomagnetic time scales. First-order correlations to paleomagnetic data are available for the Gauss, Gilbert, and Chronozones 11 through basal 8 . Second-order correlations are used for the late Miocene interval between 6.1 and $5.4 \mathrm{Ma}$, where the occurrence of warm-water radiolarians and diatoms permits correlation with established low-latitude datum levels. These biostratigraphic events are:

1) First consistent occurrence (FCO) of Cycladophora davisiana, upper Gauss Chronozone, 2.8 to $2.6 \mathrm{Ma}$.

2) Morphotypic last occurrence (Tm) of Prunopyle titan, lower Gauss Chronozone, 3.2 Ma. Lower Gauss morphotypes of $P$. titan tend to be considerably smaller (average maximum width $150-180 \mu \mathrm{m}$ ) than those in the Gilbert, where the largest morphotypes occur between 4.0 and $4.25 \mathrm{Ma}$ (average maximum width $>210 \mu \mathrm{m}$ ).

3) Evolutionary transition of Helotholus praevema to $H$. vema, at or just below the Cochiti Subchronozone, $\sim 3.95 \mathrm{Ma}$.

4) Morphotypic first occurrence ( $\mathrm{Bm})$ of Lamprocyrtis heteroporos and Tholospyris sp. A, upper Gilbert Chronozone, 3.95 Ma.

5) Tm of Triceraspyris coronata, just below the Nunivak Subchronozone, $\sim 4.25 \mathrm{Ma}$.

6) Bm of Desmospyris spongiosa, below the Nunivak Subchronozone, $4.3 \mathrm{Ma}$.

7) Tm of Amphymenium challengerae, just above or within the Sidufjall Subchronozone, $4.35 \mathrm{Ma}$.

8) Tm of Stichocorys peregrina, within the lower Gilbert Chronozone, 4.6 to $4.4 \mathrm{Ma}$.

9) $\mathrm{Tm}$ of Didymocyrtis didymus, $5.4 \mathrm{Ma}$.

10) Tm of Anthocyrtidium ehrenbergii and $\mathrm{Bm}$ of Amphymenium challengerae, $5.45 \mathrm{Ma}$.

11) Tm of Didymocyrtis sp. A and Lamprocyclas aegles group, $5.5 \mathrm{Ma}$.

12) Bm of Didymocyrtis didymus and Siphocampe sp. A and the Tm of Eucyrtidium "spp.", 5.6 Ma.

13) Bm of Didymocyrtis sp. A and Lamprocyclas aegles group, 6.0 to $5.8 \mathrm{Ma}$.

14) Bm of Stichocorys peregrina, $\sim 6.0 \mathrm{Ma}$.

15) Tm of Theocalyptra bicornis spongothorax, $8.3 \mathrm{Ma}$. This is a maximum age for this datum. It is probably younger, but can only be tied with confidence to paleomagnetic stratigraphy up through basal Chronozone 8.

16) Tm of Diartus hughesi, top of Chronozone 9, at $\sim 8.6 \mathrm{Ma}$.

17) Tm of Actinomma tanyacantha, probably within Chronozone 9, 9.5 to $9.8 \mathrm{Ma}$.

18) Bm of Theocalyptra bicornis spongothorax, basal Chronozone 9 to upper $10,9.8$ to $10.8 \mathrm{Ma}$.

19) Tm of Cyrtocapsella japonica, mid to basal Chronozone 10, 10.5 to $11.2 \mathrm{Ma}$.

Two points need to be emphasized concerning late Miocene to early Pliocene radiolarian stratigraphy. We do not have a very good understanding of lower Gilbert Magnetic Chronozone radiolarian distribution throughout the Southern Ocean (4.6 to 5.2 Ma). Eltanin Core $34-19$, which is used by Keany (1979) to zone the lower Gilbert, is equivalent to a portion of Magnetic Chronozone 6 , on the basis of data from Hole 513A. In addition, we also have very little documentation of radiolarian distributions for the interval between Magnetic Chronozones 8 and 6 . A very detailed study of existing core material is under way to try to alleviate these inadequacies.

A preliminary middle Eocene through Oligocene radiolarian datum chart is being prepared from Leg 28 , 29,36 , and 71 data. However, before it can be finished a considerable amount of taxonomic work remains to be completed. At least 60 new species are being described from Paleogene sediments recovered in Holes 511, 512, and $513 \mathrm{~A}$. These descriptions and the datum chart are being prepared for separate publication.

\section{RADIOLARIAN HOLE SUMMARIES}

\section{Hole 511}

Radiolarians are common and well preserved in Cores 1 through 20 . Cores $21,23,56$, and 57 contain rare recrystallized or poorly preserved radiolarians. All other cores are barren of siliceous microfossil remains.

\section{Age Summary}

In the absence of any well-documented high-latitude Paleogene radiolarian zonation, sediments recovered between Cores 2 and 20 are correlated with Riedel and Sanfilippo's (1978) standard low-latitude zonal scheme using rare secondary radiolarian indices. Table 1 illustrates the distribution and abundance of key radiolarian species identified in Hole 511.

Sample 511-1,CC contains a mixed assemblage of Quaternary, Pliocene, and Oligocene radiolarians indicating substantial disruption of sediments at this level. An unconformity spanning approximately 30 m.y. separates Cores 1 and 2.

Cores 2 through 4 are early Oligocene. They contain Calocycletta sp. cf. C. parva. This species is believed to be the ancestral form of $C$. parva, which appeared in the late Oligocene in low latitudes. Dinkelman (1973) reports that this species is restricted to the Theocyrtis tuberosa Zone, but Moore (1972) believes that it may range into the basal Dorcadospyris ateuchus Zone, or into the early late Oligocene. Therefore, Cores 2 through 4 are dated as early Oligocene to possibly early late Oligocene in age (Table 1). 


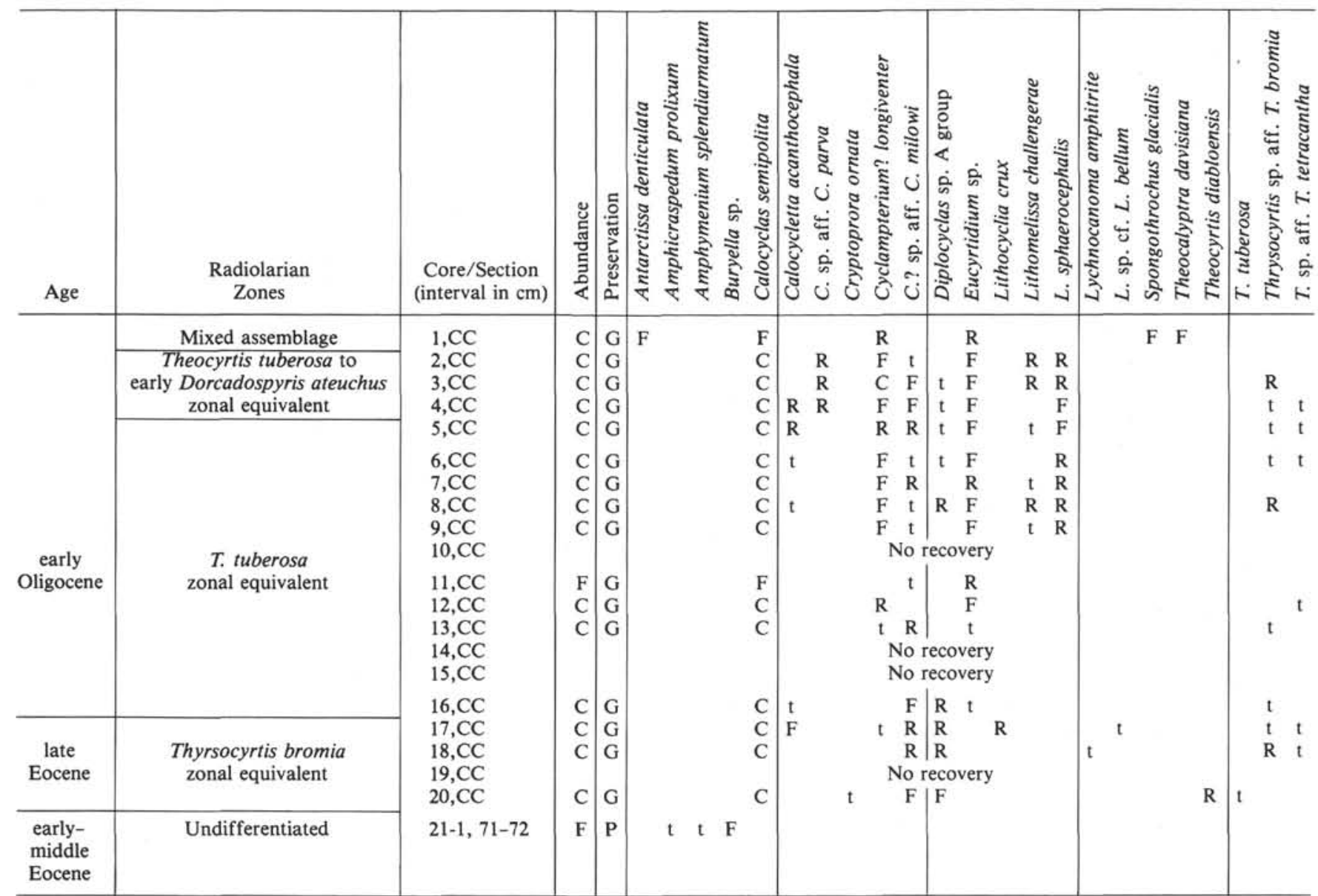

Note: For abundance, $\mathrm{C}=$ common, $\mathrm{F}=$ few, $\mathrm{R}=$ rare, $\mathrm{t}=$ trace $(1-2$ specimens/slide $)$; for preservation, $\mathrm{P}=$ poor, $\mathrm{M}=$ moderately well preserved; $\mathrm{G}=$ good.

Cores 5 through 17 are dated as early Oligocene and are correlative to the $T$. tuberosa Zone in low latitudes. This correlation is based on the occurrence of $C$. acanthocephala throughout this sequence of cores. This species is known only from the early Oligocene or $T$. $t u$ berosa Zone sediments in low- to middle-latitude regions. Johnson (1974) reports C. acanthocephala in $T$. tuberosa Zone sediments in the Indian Ocean and Ling (1975) documents its occurrence in the lower half of the T. tuberosa Zone in the Northwest Pacific area. (Core 17, however, is dated as latest Eocene on the basis of foraminiferal, calcareous nannofossil, and palynomorph data.)

Cores 18 to 20 are late Eocene in age and correlate with the Thyrsocyrtis bromia Zone in low latitudes. This age determination is based on the occurrence in these cores of Cryptoprora ornata, Lychnocanoma amphitrite, Theocyrtis diabloensis, and the ancestral form of $T$. tuberosa. Core 18 also contains very rare specimens of Thyrsocyrtis bromia and T. tetracantha.

Core 21 is tentatively dated as middle to early Eocene because of the co-occurrence of Amphymenium splendiarmatum and Amphicraspedum prolixum group along with many recrystallized specimens of Buryella species not identifiable to the specific level.

\section{Paleoenvironmental Interpretation}

The presence in Cores 16 through 20 of many specimens of Calocycletta and collosphaerid species along with specimens of Cryptoprora ornata, Theocyrtis tuberosa (ancestral form), Lychnocanoma amphitrite, $\mathrm{Li}$ thocyclia crux, and very rare Thyrsocyrtis bromia is indicative of relatively warm, possibly temperate conditions at Hole 511 during the latest Eocene and earliest Oligocene.

However, by Core 12 the specific nature of the overall radiolarian assemblage changes dramatically. Most warm-water species have disappeared and the assemblage becomes dominated by cooler water Spongoplegma, Prunopyle, and Eucyrtidium species. This assemblage persists through Core 11 and represents a significant climatic deterioration in the early Oligocene. Cores 11 and 12 appear to document the convergence of temperate and subantarctic waters after the transgression of subantarctic waters over Hole 511 in the early Oligocene.

Cores 2 through 9 contain radiolarians that resemble the early Oligocene assemblage recorded by Chen (1975) in Hole 274 at $60^{\circ} \mathrm{S}$ latitude near the Ross Sea. This assemblage is characterized by the occurrence of Cyclam- 
pterium? longiventer, Calocyclas semipolita, Amphisphaera sp., Diplocyclas sp. A group, Lithomelissa sphaerocephalis, L. challengerae, Spongomelissa sp., and Eucyrtidium sp. (Table 1).

Chen (1975) records this assemblage in Cores 274-31 through 274-39. Because of their proximity to the Antarctic continent, these radiolarians are considered to be relatively cool-water species. Radiolarians in Cores 5112 through 511-9 appear to represent the northerly elements of a broad antarctic/subantarctic biofacies that encompassed up to 18 degrees of latitude in the circumAntarctic seas during the early Oligocene.

In summary, climatic conditions through the late Eocene to early Oligocene at Hole 511 fluctuate from temperate to at least subantarctic.

\section{Holes 512 and 512A}

Nineteen HPC cores were recovered at Hole 512 and one conventional core at Hole 512A. Very well preserved, abundant, and highly diverse radiolarians are encountered in all cores.

\section{Miocene}

Samples $512-1-1,139-141 \mathrm{~cm}$ to $512-5, \mathrm{CC}$ are correlated with the Miocene Actinomma tanyacantha Radiolarian Zone (Table 2). This interval spans the late/middle Miocene boundary, based upon foraminiferal data. The paleomagnetic stratigraphy of these sediments is interpreted by Ciesielski (this volume) to represent much of Chronozone 10 and the top of Chronozone 11 or the base of Chronozone 10 and most of Chronozone 11. However, without a more continuous section, it is impossible to say definitively which interpretation is correct.

The radiolarian assemblage encountered in Cores 512-1 through 512-5 is repetitious and is dominated by Dendrospyris haysi, Prunopyle hayesi, Antarctissa conradae, Cornutella profunda, Theocalyptra bicornis, Eucyrtidium cienkowskii group, and Siphocampe arachnea group. Less abundant species include Cyrtopera laguncula, Actinomma tanyacantha, Lychnocanoma grande, and Gondwanaria japonica. The only noticeable change in species composition occurs between Sections 512-3-2 and 512-2-2, where Cyrtocapsella japonica is documented (Table 2). The morphotypic top of $C$. japonica in low latitudes is within the Diartus petterssoni Zone (Johnson and Wick, 1982). They correlate this datum with the Chron 10/11 boundary at approximately $11.2 \mathrm{Ma}$.

The occurrence of many known deep-living radiolarian species such as Cyrtopera laguncula, Cornutella profunda, Peripyramis circumtexta, and S. arachnea group together with common to abundant Thalassiothrix spp. (diatom) throughout Cores 512-1 through 512-5 reflects eutrophic conditions. This association of diatoms and radiolarians is indicative of upwelling conditions (Weaver et al., 1981) and leads to the conclusion that Hole 512 was at or very near the Polar Front Zone between 11.5 and $10 \mathrm{Ma}$.

\section{Eocene}

Cores 512-6 through 512-19 and Core 512A-2 contain excellently preserved radiolarians dated as middle Eo- cene. No Paleogene zones exist at middle to high latitudes and no direct correlation to Riedel and Sanfilippo's (1978) low-latitude zonation is possible because of the paucity of stratigraphically important, low-latitude, index species. However, an indirect correlation is possible using secondary marker species such as Eusyringium fistuligerum, E. lagena, Lithapium mitra, and Lophocyrtis biaurita (Table 2).

Eusyringium fistuligerum, E. lagena, and Lophocyrtis biaurita range throughout Cores 512-6-19 and 512A2 (Table 2). Lithapium mitra is found only in Cores 512-9 and 512-17. Based on radiolarian distributions at low latitudes, the highest occurrence of $L$. biaurita and the lowest occurrence of $L$. mitra are within the Podocyrtis mitra Zone. This interval is correlative with the NP15-NP16 nannofossil zones. While $E$. fistuligerum first occurs in low latitudes within the Thyrsocyrtis triacantha Zone, it co-occurs with $E$. lagena primarily within the Podocyrtis ampla to P. mitra zones. Therefore, based upon the occurrence of these secondary marker species, Cores 512-6-19 and 512A-2 are constrained to the P. mitra to P. ampla zones of Riedel and Sanfilippo, 1978 (Table 2).

The composite middle Eocene radiolarian assemblage at Holes 512 and $512 \mathrm{~A}$ is dominated by Cyclampterium? sp. aff. C. milowi, Lychnocanoma bellum, $L$. sp. cf. $L$. bellum, L. amphitrite, Periphaena decora, Theocotylissa sp. aff. T. ficus, Dictyoprora mongolfieri, Phormocrytis embolum, Lophocorys sp. aff. L. norvegiensis, and Lophocyrtis biaurita. Numerous other new theoperid species were found within this interval and are now being described for publication.

\section{Holes 513 and 513A}

Radiolarians are common and well preserved throughout all cores recovered at Holes 513 and 513A. Ten cores were taken at Hole 513 and 33 at Hole 513A. Sediments range in age from Quaternary to early Oligocene.

Sample 513-1,CC contains a typical late Quaternary $(<400,000 \mathrm{yr}$.) antarctic radiolarian assemblage that can be assigned to the Antarctissa denticulata Zone. Common species include $A$. denticulata, A. strelkovi, Stylodictya validispina, Cycladophora davisiana, Lithelius nautiloides, Saccospyris antarctica, and Actinomma antarcticum. The high abundance of $A$. antarcticum in this sample probably indicates proximity to the Polar Front Zone. Sample 513-3,CC is within the Saturnalis circularis Zone (approximately 0.7 to $1.6 \mathrm{Ma}$ ). This core catcher sample contains Quaternary radiolarians restricted to waters south of the Polar Front. Sample 513-4,CC is also in the $S$. circularis Zone, but it is below the morphotypic top of Clathrocyclas bicornis (1.6-1.8 Ma).

Sample 513-5,CC falls within the late Pliocene Eucyrtidium calvertense Zone (1.8-2.4 Ma). Typical late Pliocene antarctic radiolarians dominated by Antarctissa denticulata and Spongotrochus glacialis are present and indicate a position south of the Polar Front. The radiolarians in Sample 513-6,CC correlate to the upper part of the Helotholus vema Zone within the Gauss Magnetic Chronozone. No sediments were recovered from Cores 513-6-7. The early Pliocene Triceraspyris coronata Zone is represented in Samples 513-9,CC and 513-10,CC. 
Table 2. Radiolarians, Holes 512 and 512A.

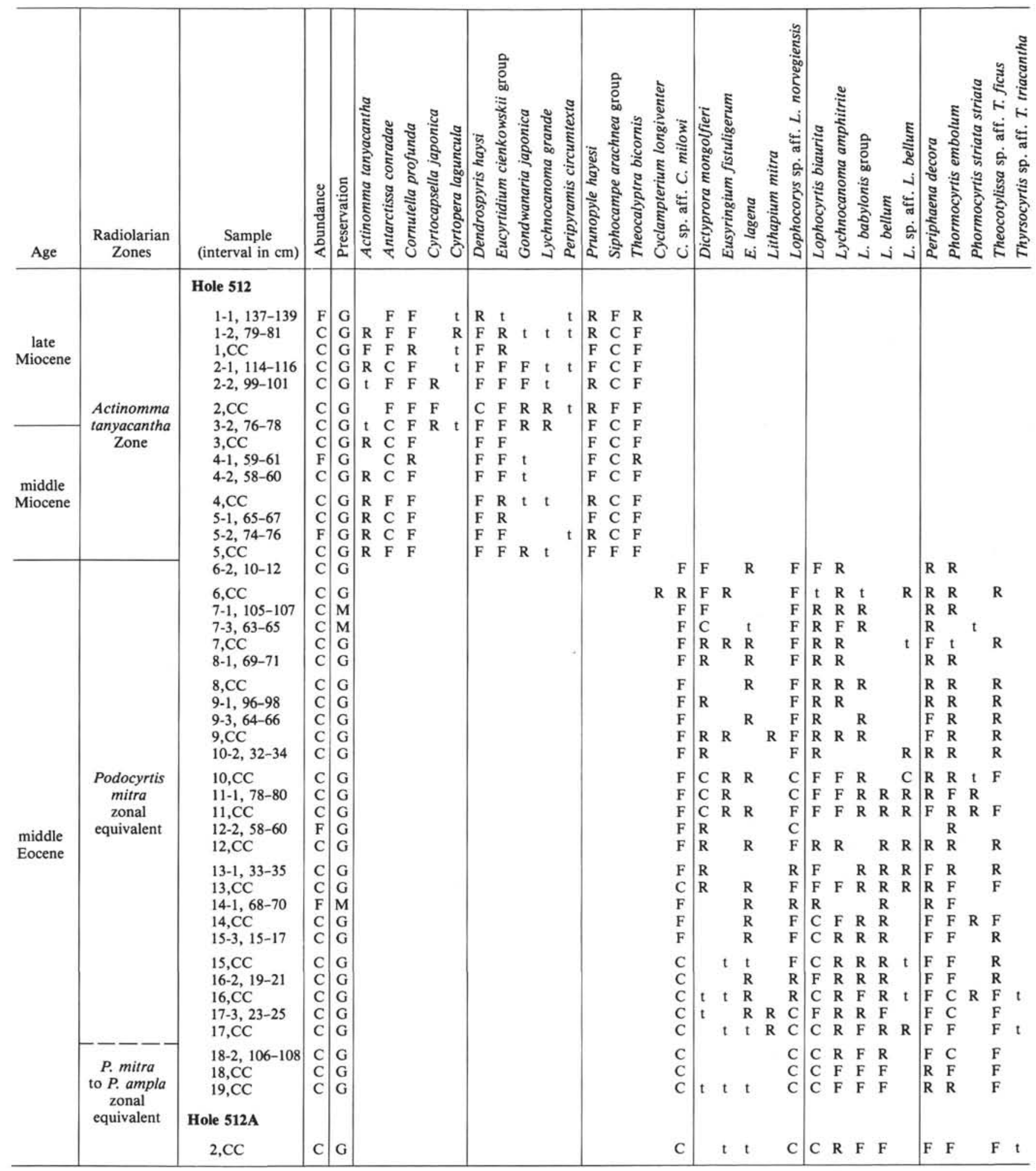

Note: For abundance, $\mathrm{C}=$ common, $\mathrm{F}=$ few, $\mathrm{R}=$ rare, $\mathrm{t}=$ trace $(1-2$ specimens $/$ slide $)$, for preservation, $\mathrm{P}=$ poor, $\mathrm{M}=$ moderately well preserved; $\mathrm{G}=\mathrm{good}$.

Characteristic species include $T$. coronata, $H$. praevema, C. bicornis, Eucyrtidium calvertense, and Stylatractus universus.

Sample $513 \mathrm{~A}-1, \mathrm{CC}$ is assigned to the lower part of the early Pliocene $H$. vema Zone. Along with species typical of this zone (Chen, 1975) are found many warm- water species, including Lamprocyclas maritalis, Dictyocoryne profunda/truncatum group, Tholospyris $\mathrm{sp}$. A, Pterocanium trilobum, Lamprocyrtis heteroporos, and many collosphaerids. Samples 513A-2,CC to 513A-4,CC are also early Pliocene and fall within the Triceraspyris coronata Zone (Table 3). $T$. coronata and $H$. praevema 
are common constituents in Samples 513A-3,CC and $513 \mathrm{~A}-4, \mathrm{CC}$. This interval is correlative with Samples $513-9, C C$ and 513-10,CC. The Stichocorys peregrina Zone is represented in Cores 513A-5 through 8. The Miocene/Pliocene boundary occurs within this zone at an apparent hiatus between Cores 4 and 5 (based on diatom data; Ciesielski, this volume). Diatom data further indicates that the interval between Section 513A-8-3 and 513A-5-5 correlates with upper Magnetic Chronozone 6 to lower Chronozone 5 (Ciesielski, this volume; Haq et al., 1980; Saito et al., 1975). Section 513A-8-4 Core $513 \mathrm{~A}-6$ is characterized by relatively warm water siliceous fauna and flora which allow a reliable correlation to low-latitude zonations. Warm-water radiolarians include Anthocyrtidium ehrenbergii, Didymocyrtis didymus, D. sp. A, Lamprocyclas aegles group, Heliodiscus asteriscus, and Stichocorys peregrina (Table 3). Radiolarians indicate that Hole 513A was situated north of the Polar Front between approximately 6.3 and $5.6 \mathrm{Ma}$.

A significant transition in the radiolarian fauna is observed between Cores 513A-6 and 5. In Core 5, most warm-water radiolarians have disappeared. Radiolarian abundances are greatly reduced and deeper-living forms such as Siphocampe arachnea group, Cyrtopera laguncula, Cornutella profunda, and Peripyramis circumtex$t a$ become progressively more dominant, especially between Sections 513A-5-4 and 513A-5-1. In contrast to Core 6 , Core 5 contains a very high concentration of the diatom Thalassiothrix spp. This occurrence, together with the concentration of deep-living radiolarians, strongly suggests increased upwelling and very high productivity in the latest Miocene at Hole 513A. It further signals the late Miocene ( 5.6-5.4 Ma) northward migration of the Polar Front to a position at or very near Hole 513A. This would be at least a degree or two north of its present position in the Southern Ocean today.

Very little sediment was recovered in Core 513A-9; however, Sample 513A-9,CC is tentatively dated as late Miocene, although it may be contaminated and unreliable for age analysis. Sections 513A-10-1 through 513A11-1 fall within the Theocalyptra bicornis spongothorax Zone (Table 3). The last occurrence of Diartus hughesi

Table 3. Neogene radiolarians, Hole 513A.

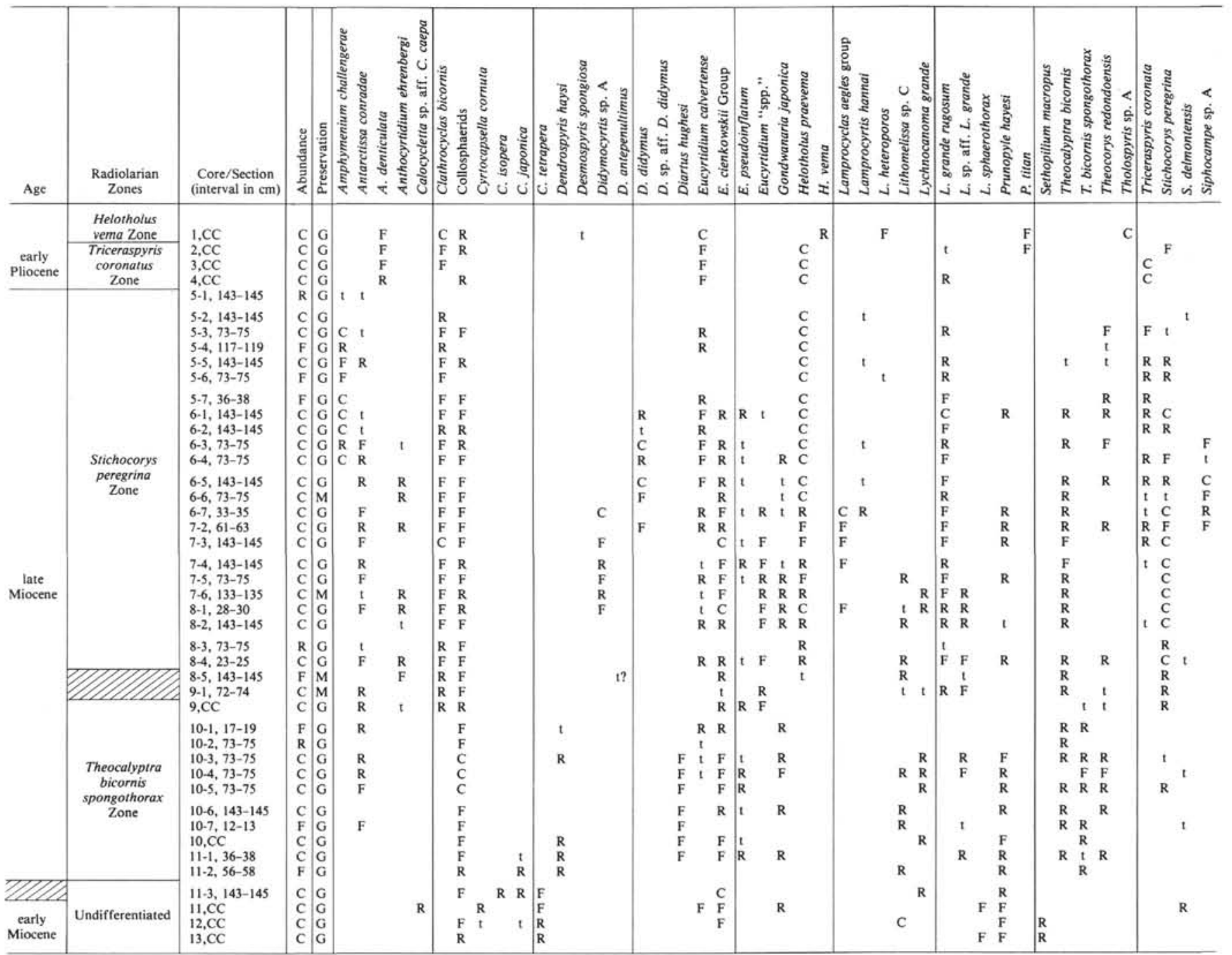

Note: For abundance, $\mathrm{C}=$ common, $\mathrm{F}=$ few; $\mathrm{R}=$ rare; $\mathrm{t}=$ trace $(\mathrm{I}-2$ specimens slide); for preservation, $\mathrm{P}=$ poor, $\mathrm{M}=$ moderately well preserved, preserved, $\mathrm{G}=\mathrm{good}$. 
is in Section 513A-10-3 (Table 3). This datum occurs at the top of Chron 9 in low latitudes at approximately 8.6 Ma. (Johnson and Wick, 1982). A radiometric age determination on an ash layer in Section 513A-10-7 yields an age of 8.7 m.y. \pm 0.2 (Ciesielski, this volume). These data suggest that Core 513A-10 to Section 513A-11-1 correlates to the late Miocene Magnetic Chron 9. Section 513A-11-3 to Sample 513A-11,CC is middle to early Miocene, based upon the co-occurrence of Cyrtocapsella cornuta and $C$. tetrapera. Although the radiolarian assemblage is diverse and well preserved, neither lownor high-latitude index species are present. Chen's (1975) and Riedel and Sanfilippo's (1978) zonations are not applicable. Cores 12 through 14 are early Miocene, based on silicoflagellate data. Radiolarians encountered in this interval are very diverse, as in Core 11, and correspondingly bear very little similarity to the early Miocene radiolarians known from low or high latitudes. Apparently these radiolarians represent a somewhat restricted early Miocene temperate biofacies. Radiolarians identified include C. cornuta, C. tetrapera, Sethopilium macropus, Prunopyle hayesi, Lychnocanoma sphaerothorax, Lithomelissa sp. C, Eucyrtidium cienkowskii group, and many species of collosphaerids. Many previously undefined species are being described from this interval.

Cores 513A-15 through 33 are dated as Oligocene. Radiolarians in these sediments are well preserved and very diverse but, as reported for the early Miocene assemblage, bear very little resemblance to low-latitude, time-equivalent faunas. Many undescribed species are present. Only four radiolarians reported from low-latitude sediments are observed within this interval: Theocorys spongoconum, Artophormis gracilis, and two species figured by Riedel and Sanfilippo (1977, plate 14, figs. 19-20, both listed as "theoperids gen. et sp. indet."').

A significant faunal change occurs between Cores 513A-28 and 27. Samples from Cores 28-33 correlate with Cores 511-2 through 6 or 7 on the Falkland Plateau. This stratigraphic overlap between Holes 511 and $513 \mathrm{~A}$ provides an apparently complete Oligocene section situated in the cool temperate to subantarctic region of the Southwest Atlantic.

\section{Hole 514}

Quaternary to Pliocene radiolarians are present in all 35 HPC cores recovered at Hole 514. Abundance and diversity are high and preservation generally good. Hole 514 appears to be stratigraphically uninterrupted down to the Core 26/27 boundary, where an unconformity of approximately 700,000 yr. separates Gauss from upper Gilbert sediments.

Table 4 illustrates the occurrence and abundance of radiolarian species in Hole 514. Based on paleomagnetic stratigraphy, the Quaternary/Pliocene boundary occurs between Cores 4 and 5 .

Core 514-1 falls within the Antarctissa denticulata Zone, Core 514-2 the Stylatractus universus Zone, Cores 514-3 through 5 the Saturnalis circularis Zone, Cores 514-6 to 10 the Eucyrtidium calvertense Zone and Cores 514-11 to 35 the Helotholus vema Zone (Table 4). Ra- diolarian zones and the range correlations of key species to the paleomagnetic time scale agree with the earlier data of Hays (1965) and Hays and Opdyke (1967).

\section{Polar Front Migration}

One of the primary objectives of Leg 71 was to collect a continuously cored late Cenozoic section near the modern position of the Antarctic Polar Front in order to document its evolution and migration through time.

Radiolarian assemblage analyses in Hole 514 record eight separate northward shifts in the Polar Front over this site during the Pliocene and Quaternary. These shifts are:

1) 3.9-4.0 Ma, Gilbert

2) $3.1 \mathrm{Ma}$, Gauss

3) $2.6-2.7 \mathrm{Ma}$, Gauss

4) $2.5 \mathrm{Ma}$, Gauss

5) $1.9-2.4 \mathrm{Ma}$, Matuyama

6) $1.9-2.4 \mathrm{Ma}$, Matuyama

7) $1.6 \mathrm{Ma}$, Matuyama

8) 0.4-0.7 Ma, Brunhes

Details of Polar Front migrations observed from radiolarians in Hole 514 are provided in Ciesielski and Weaver (this volume). Because of the major faunal reorganization at approximately $2.5 \mathrm{Ma}$ (Hays and Opdyke, 1967), Polar Front history must be examined over two intervals, post-Gauss and pre-Matuyama. Post-Gauss Polar Front movements are documented by comparing downhole variations in radiolarian biofacies to their modern spatial distributions relative to the Polar Front Zone. Modern radiolarian biogeography is established using data from Hays (1965), Payne (1977), Nigrini (1967), Lozano and Hays (1976), Hays and Opdyke (1967), Petrushevskaya (1967), and Moore and Nigrini (1978). Latest Quaternary radiolarians indicative of waters north of the modern Polar Front include Heliodiscus asteriscus, Pterocorys zancleus, Eucyrtidium acuminatum, Dictyocoryne profunda/truncatum group, Lamprocyclas maritalis, and Pterocanium praetextum eucolpum. The biofacies restricted to the area near and south of Polar Front waters includes Antarctissa denticulata, A. strelkovi, Saccospyris antarctica, Lithelius nautiloides, Triceraspyris antarctica, and Actinomma antarcticum. Samples with significant numbers of $A$. antarcticum are presumed to record a position at or very near the Polar Front.

Identifying Polar Front movements in pre-Matuyama sediments presents a more difficult problem because of the increase in radiolarian species that are now extinct and about the paleoecology of which we know very little. However, detailed analyses of Pliocene radiolarian biogeography have identified several species with a restricted regional distribution that is almost certainly controlled by the position of the Pliocene Polar Front Zone. Data from Chen (1975), Weaver (1976a), Keany (1979), Hays and Opdyke (1967), and Hays (1965) are used to select those species.

Pre-Matuyama Pliocene radiolarians used to discern waters north of the Polar Front include Lamprocyrtis heteroporos, Tholospyris sp. A, Lamprocyclas maritalis, Dictyocoryne profunda/truncatum group, and col- 
losphaerids (with very large pores). Species used to establish a position at or south of the Polar Front are Desmospyris spongiosa, Helotholus vema, Antarctissa denticulata, and $A$. strelkovi. The spatial distribution of these two radiolarian groups is similar to the two major radiolarian biofacies in modern antarctic and subantarctic waters.

\section{LIST OF SPECIES}

The following list provides a bibliography of references along with some observations of radiolarian taxa identified in Leg 71 sediments. In most cases the original author is cited along with an additional reference that contains information on the current concept of the species. Additionally, several new species are described and illustrated.

Actinomma antarcticum (Haeckel) Nigrini, 1967, p. 26, pl. 2, figs. la-d; Hays (1965), pp. 165-167, pl. 1, fig. 1.

Actinomma tanyacantha Chen, 1975 , pp. $450-452$, pl. 11, figs. 5-6. Plate 5, Figure 3.

Amphicraspedum prolixum Sanfilippo and Riedel, 1973, p. 524, pl. 10 , figs. 7-11.

Amphirhopalum ypsilon Haeckel, 1887, p. 522; Nigrini, 1967, p. 35 , pl. 3, figs. 3a-d.

Amphymenium challengerae n. sp. (Plate 6, Figures 1-2).

Description. Shell with two opposite segmented arms generally consisting of 4 to 5 distinct segments which are convex distally. Each arm segment penetrated by internal spines as basic framework; each segment covered by lattice work of circular to subcircular pores. Internal spines extend beyond shell segments as short projections. Arms arise from central structure composed of 2 inner spherical shells and 2 outer oblate spheroidal shells, all smooth and connected by numerous beams. In well-preserved specimens a patagium occurs around central structure and most chambered arm segments.

Measurements. Total length, $220-260 \mu \mathrm{m}$; length of arm, 75-95 $\mu \mathrm{m}$; maximum width of arm, 90-105 $\mu \mathrm{m}$; length of central structure, $85-100 \mu \mathrm{m}$; width, $75-95 \mu \mathrm{m}$. Measurements based on 25 specimens from $540 \mathrm{~cm}$ in Eltanin Core 16-4.

Abundance. Rare to common.

Occurrence. late Miocene to early Pliocene.

Type locality. E16-4, $540 \mathrm{~cm}$.

Amphymenium splendiarmatum Clark and Campbell, 1942, p. 46, pl. 1, figs. 12, 14; Sanfilippo and Riedel, 1973, p. 524, pl. 11, figs 6-8; pl. 28, figs. 6-8.

Amphisphaera sp. Chen, 1975, p. 453, pl. 6, figs. 1-2.

Antarctissa conradae Chen, 1975, p. 457, pl. 17, figs. 1-5.

Antarctissa denticulata (Ehrenberg) Petrushevskaya, 1968, pp. 84-86, fig. 49, I-IV; Chen, 1975, p. 457, pl. 18, figs. 3-8. Plate 1, Figure 7.

Antarctissa strelkovi Petrushevskaya, (1968), pp. 88-90, fig. 51, IIIVI.

Anthocyrtidium ehrenbergi (Stohr) Haeckel, 1887, p. 1277; Riedel, 1957 , p. 83, pl. 20, figs. 1-9. Plate 4, Figure 6.

Artophormis gracilis Riedel, 1959, p. 300, pl. 2, figs. 12-13; Moore, 1971 , p. 742 , pl. 5 , figs. $10-11$.

Botryostrobus miralestensis (Campbell and Clark) Petrushevskaya and Kozlova, 1972, p. 539, pl. 24, fig. 31; Nigrini, 1977, p. 249, pl. 1, fig. 9.

Buryella sp. Recrystallized specimens not recognized to the species level.

Calocyclas semipolita Clark and Campbell, 1942, p. 83, pl. 8, figs. 12, 14, 17-19, 21-23; Chen, 1975, p. 459, pl. 6, figs. 3-6.

Calocycletta acanthocephala (Ehrenberg) Petrushevskaya and Kozlova, 1972, p. 544, pl. 35, figs. 5-7; Johnson, 1974, p. 550, pl. 6 , fig. 3.

Calocycletta sp. cf. C. parva Dinkelman, 1973, pl. 7, fig. 3.

Calocycletta sp. aff. C. caepa Moore, 1972.

Clathrocyclas bicornis Hays, 1965, p. 179, pl. 3, fig. 3; Chen, 1975, p. 489 , pl. 12, figs. 8-9. Plate 2, Figure 5.

Collosphaera sp.

Cornutella profunda Ehrenberg, 1858, p. 31; Riedel, 1958, p. 232, pl. 3, figs. 1-2. Plate 1, Figure 6.
Cyrtoprora ornata Ehrenberg, 1874, p. 222; Riedel and Sanfilippo, 1971, pl. 3D, figs. 10-11; Sanfilippo and Riedel, 1973, p. 530, pl. 35 , figs. 3-4.

Cycladophora davisiana Ehrenberg, 1862, p. 297; Riedel, 1958, p. 239, pl. 4, figs. 2-3; Weaver, 1976a, p. 581, pl. 1, fig. 7. Plate 1, Figure 3.

Cyclampterium? longiventer Chen, 1975, pp. 459-460, pl. 10, fig. 7.

Cyclampterium? sp. aff. C. milowi Riedel and Sanfilippo, 1971. Specimens have a very large inflated abdomen with large pores similar to $C$. milowi, but lack the well-developed latticed feet.

Cyrtocapsella cornuta (Haeckel) Riedel and Sanfilippo, 1978, p. 68, pl. 4 , fig. 17.

Cyrtocapsella isopera Chen, 1975, p. 460, pl. 11, figs. 7-9; Weaver, 1976 a, p. 581, pl. 3, figs. 5-6; pl. 9, figs. 4, 6 .

Cyrtocapsella japonica (Nakaseko) Sanfilippo and Riedel, 1970, p. 452, pl. 1, figs. 13-15; Kling, 1973, p. 636, pl. 11, figs. 19-20.

Cyrtocapsella tetrapera (Haeckel) Riedel and Sanfilippo, 1978, p. 68, pl. 4, fig. 18; Weaver, 1976a, p. 581, pl. 3, figs. 1-3; pl. 9, figs. 1-3, 7. Plate 6, Figure 4.

Cyrtopera laguncula Haeckel, 1887, p. 1451, pl. 75. fig. 10; Chen, 1975 , p. 460 , pl. 18 , fig. 9 .

Dendrospyris haysi Chen, 1975 , p. 455 , pl. 15, figs. 3-5; Weaver, 1976a, p. 579, pl. 2, figs. 7-9; pl. 7, fig. 4. Plate 5, Figure 4.

Desmospyris spongiosa Hays, 1965, pp. 173-175, pl. 2, fig. 1; Weaver, 1976a, p. 579, pl. 1, fig. 12; Chen, 1975, p. 456, pl. 15, figs. 1-2. Plate 2, Figures 6-8.

Dictyocoryne profunda/truncatum group Ehrenberg, 1872, p. 307, pl. 7, fig. 23.

Dictyoprora mongolfieri (Ehrenberg) Nigrini, 1977, pp. 250-251, pl. 4, fig. 7; Riedel and Sanfilippo, 1978, p. 76, pl. 9, fig. 13.

Didymocyrtis sp. A. Similar to Ommatartus sp. A Foreman, 1975, p. 618 , pl. 8 , figs. $20-23$, but much more heavily silicified. Plate 6 , Figure 5.

Didymocyrtis antepenultimus (= Ommatartus antepenultimus) Riedel and Sanfilippo, 1978, p. 71, pl. 7, fig. 6. Plate 5, Figure 2.

Didymocyrtis didymus Ehrenberg, 1844, p. 83; Riedel et al., 1974, p. 706, pl. 55, figs. 3-5; Zachariasse et al., 1978, p. 105, pl. 2, figs. 10-11. High-latitude forms of this Didymocyrtis species encountered in Hole 513A sediments are similar to those referred to as Ommatartus didymus by Riedel et al., 1974. These forms have large multiple polar caps. Sanfilippo et al., 1973, have suggested that $D$. didymus is a cold-water form of Diartus hughesi. If this is true, then Didymocyrtis didymus persisted at high latitudes for a considerable time after Diartus hughesi became extinct in low-latitude regions. Plate 6, Figures 7-8.

Didymocyrtis sp. aff. D. didymus (Ehrenberg, 1844).

Diartus hughesi (= Ommatartus hughesi) (Campbell and Clark) Riedel and Sanfilippo, 1978, p. 71, pl. 7, fig. 7. Plate 5, Figure 1.

Diplocyclas sp. A group Chen, 1975, p. 460, pl. 7, figs. 4-5.

Eucyrtidium acuminatum Ehrenberg, 1844, p. 84; Nigrini, 1967, p. 81 , pl. 8, figs. 3A, B.

Eucyrtidium calvertense Martin, 1904, p. 450, pl. 130, fig. 5; Hays, 1965 , p. 181, pl. 3, fig. 4; Weaver, 1976a, p. 581. pl. 1, fig. 9. Plate 2, Figure 9; Plate 4, Figure 7.

Eucyrtidium cienkowskii group Haeckel, 1887, p. 1493, pl. 80, fig. 9; Weaver, 1976a, p. 581, pl. 4, figs. 3-5; pl. 8, figs. 7-9. Plate 5, Figure 6.

Eucyrtidium pseudoinflatum n. sp. (Plate 5, Figures 8-9). Description. Shell truncate fusiform, inflated; abdomen and postabdominal segments are marked or separated by internal septa. Cephalis spherical, partially sunken into the thorax. Contains a few small, circular pores. Collar stricture generally slight or indistinct. Thorax inverted conical with 4-5 rows of small pores arranged in desicussate rows. Lumbar stricture marked by distinct change in contour. Abdominal segment contains 7-8 longitudinal furrows in which lie circular pores approximately twice the size of the thoracic pores. Shell reaches maximum width within this segment. First postabdominal segment truncate conical, approximately half the length of the abdomen; contains an equal number of furrows, and pores of a smaller diameter. In well-preserved specimens there is a second postabdominal segment that is truncate conical and contains only a few small, irregularly spaced pores. Discussion. E. pseudoinflatum resembles $E$. inflatum Kling, 1973, in its overall size and inflated appearance. However, it differs 
Table 4. Radiolarians, Site 514.

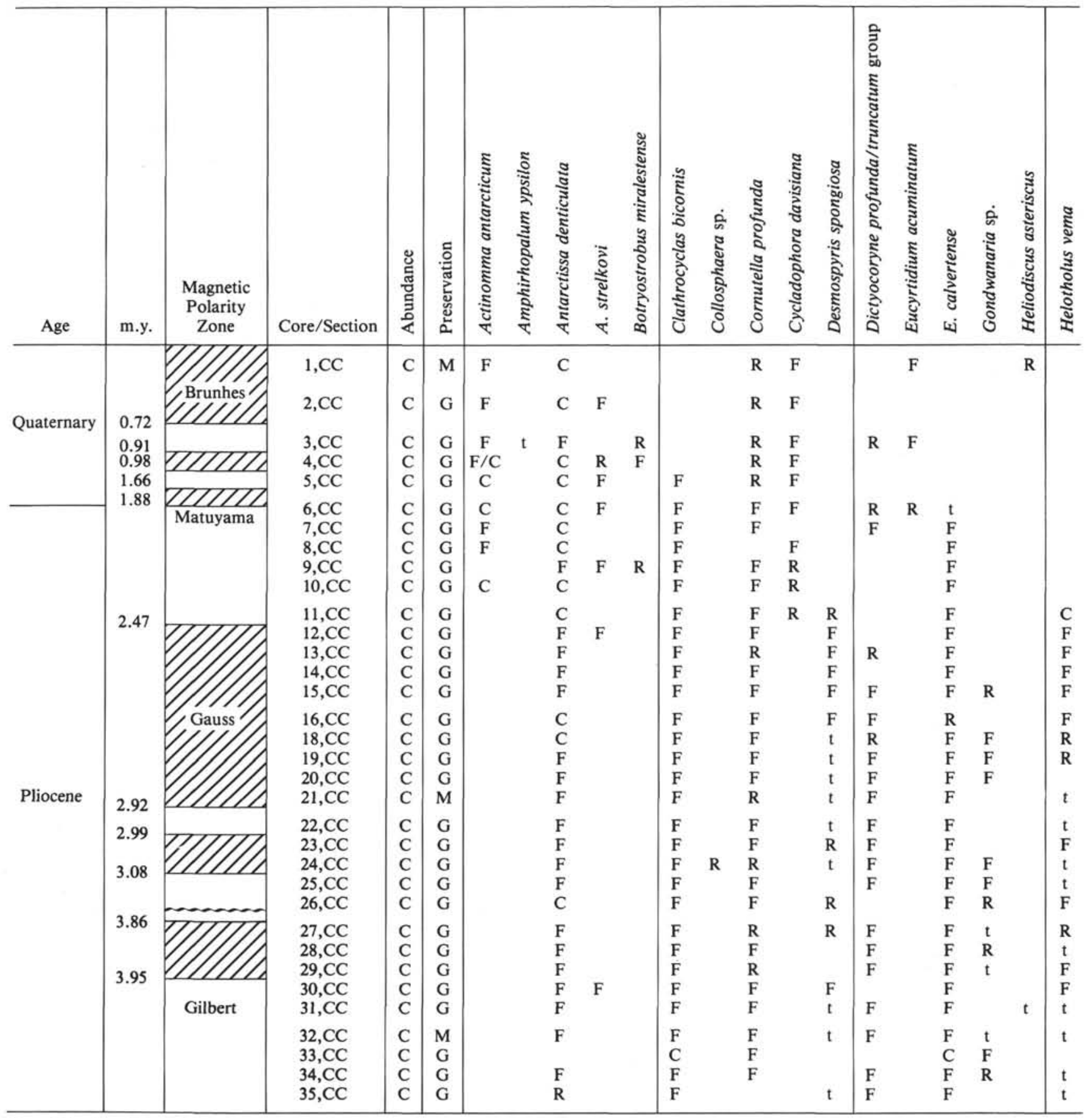

Note: For abundance, $\mathrm{C}=$ common, $\mathrm{F}=$ few, $\mathrm{R}=$ rare, $\mathrm{t}=$ trace $(1-2$ specimens/slide); for preservation, $\mathrm{P}=$ poor $\mathrm{M}=$ moderately well preserved, $\mathbf{G}=$ good.

from $E$. inflatum in having a greater number of longitudinal furrows, smaller pore diameter, and a maximum width which is attained in the mid to upper first abdominal segment. E. inflatum Kling attains a maximum width in the lowermost abdomen or at the division of the abdomen and fourth segment.

Measurements. Total length of shell, 145-175 $\mu \mathrm{m}$; cephalis, 15-22 $\mu \mathrm{m}$; thorax, 30-38 $\mu \mathrm{m}$; abdomen, 50-75 $\mu \mathrm{m}$; all postabdominal segments, 35-52 $\mu \mathrm{m}$; maximum shell width, 90-110 $\mu \mathrm{m}$; diameter of pores, 2-6 $\mu \mathrm{m}$. Measurements based on 25 specimens from DSDP Samples $278-10-2,43-45 \mathrm{~cm}, 278-10-3,48-50 \mathrm{~cm}$, and 278-10-4, 54-56 cm.

Abundance. rare to few.
Occurrence. late Miocene.

Type locality. DSDP Sample $278-10-3,48-50 \mathrm{~cm}$.

Holotype. Plate 5, Figures 8-9.

Eusyringium fistuligerum (Ehrenberg) Riedel and Sanfilippo, 1978, p. 68 , pl. 5, figs. 6-7.

Eusyringium lagena (Ehrenberg) Riedel and Sanfilippo, 1978, p. 68, pl. 5 , fig. 8.

Eucyrtidium sp. Chen, 1975 , p. 461 , pl. 7, figs. 6-8.

Eucyrtidium "spp." Sanfilippo and Riedel, 1970, p. 450, fig. 1.

Gondwanaria japonica (Nakaseko) Petrushevskaya, 1975, p. 584, pl. 8 , fig. 15 ; pl. 9, figs. $2-7$; pl. 12 , fig. 1 .

Gondwanaria sp. 
Table 4. (Continued).

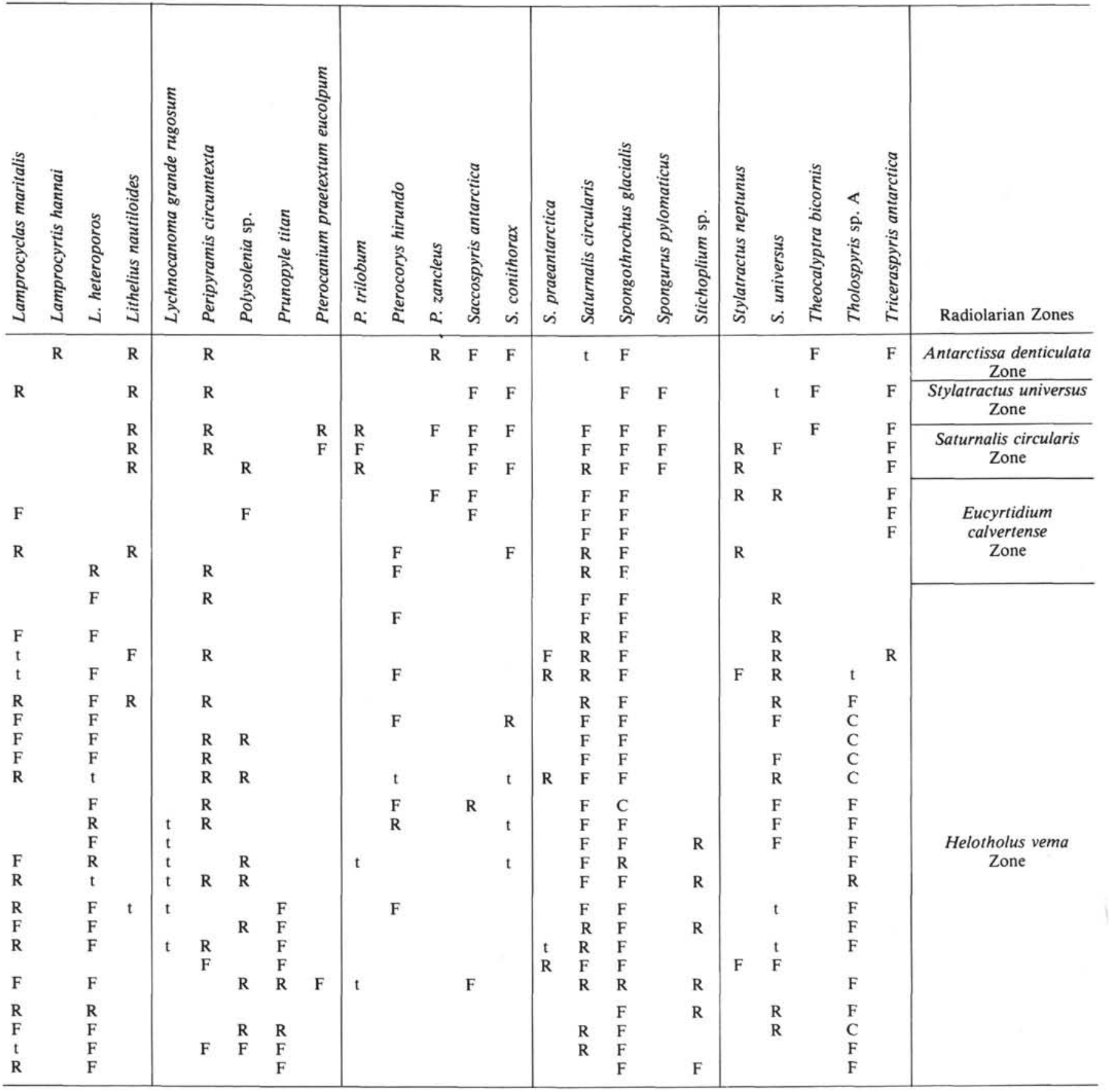

Heliodiscus asteriscus Haeckel, 1887, p. 455, pl. 33, fig. 8; Hays, 1965 , p. 171, pl. 2, fig. 7.

Helotholus praevema n. sp. (Plate 3, Figs. 1, 5-15).

Description. Shell consists of two segments. Cephalis spherical, with numerous circular to subcircular pores and 1 or 2 apical spines. Cephalis width, one-half to two-thirds thorax. Collar stricture is distinct. Thorax variable, predominantly subcylindrical, sometimes cup-shaped, with numerous circular to elliptical pores. Commonly pores are irregularly spaced or exhibit crude longitudinal alignment. In well-preserved specimens, supplementary spines protrude from thoracic wall as apparent extensions of the internal structure. Internal structure consists of the elements $\mathrm{A}, \mathrm{D}, \mathrm{V}, \mathrm{Lr}$, and $\mathrm{L} 1$ spines, all arising from a common point in plane of collor stricture. An axial spine (Ax) projects downward into thoracic cavity from this point. No distinct median bar (Mb) observed; point of convergence of internal spines could be perceived as short $\mathrm{Mb}$. Where primary interval spines are fused to thoracic wall, it is drawn into shell, forming grooves on surface.

Discussion. The internal structure of Helotholus praevema closely resembles that of $H$. histricosa Jorgensen. $H$. praevema might become confused with Antarctissa strelkovi, but it differs from this species in having a distinct collar stricture. The internal structure also differs from $A$. strelkovi and $H$. histricosa sensu Riedel, 1958, in that these species have a distinct $\mathrm{Mb}$ (see fig. 51.6, Petrushevskaya, 1967 , p. 89 , and Riedel, 1958 , p. 235 , figs. 6-7). $H$. praevema evolved to $H$. vema just prior to the Cochiti Subchron. This species transition during the early Pliocene involves (1) almost two fold increase in thoracic width, (2) a gradual invagination of the cephalis into the thorax (Kellogg, 1975), (3) the formation of up to 12 large subcircular to elliptical pores on the flat 
horizontal portion of the upper thorax, and (4) a transformation of the internal structure by the development of a basal ring and several horizontal and oblique beams that connect it to the thoracic wall. Kellogg (1975) considered $H$. praevema and $H$. vema to be the same species, and documented this evolutionary transition as directional selection for larger phenotypes of the same species. Just prior to the evolutionary transition of $H$. praevema to $H$. $v e m a$, the cephalis became slightly invaginated into the thorax, and some specimens could become confused with A. strelkovi. Examination of the internal structure, however, would prove definitive.

Measurements. Length of shell, $90-160 \mu \mathrm{m}$; cephalis, 38-55 $\mu \mathrm{m}$; maximum width of thorax, 70-135 $\mu \mathrm{m}$. Measurements based on 100 specimens from Eltanin Core E 50-28, $411 \mathrm{~cm}, 380 \mathrm{~cm}$; Core E $38-8,460 \mathrm{~cm}, 480 \mathrm{~cm}$, and $540 \mathrm{~cm}$.

Abundance. rare to common.

Range. late Miocene to early Pliocene.

Type locality. E 38-8, $500 \mathrm{~cm}$.

Holotype. Plate 3, Figure 9.

Helotholus vema Hays, 1965, p. 176, pl. 2, fig. 3; Chen, 1975, p. 457 , pl. 16, figs. 1-4; Weaver, 1976a, p. 580, pl. 1, figs. 10-11. Plate 3 , Figures 2-4.

Lamprocyclas aegles group (Ehrenberg) Petrushevskaya and Kozlova, 1972, p. 544, pl. 36, fig. 13. Plate 4, Figures 4-5.

Lamprocyclas maritalis Haeckel; Nigrini, 1967, p. 74, pl. 7, fig. 5. Plate 4, Figure 8.

Lamprocyrtis hannai (Campbell and Clark) Kling, 1973, p. 638, pl. 5, figs. $12-14$; pl. 12 , figs. 10-14.

Lamprocyrtis heteroporos (Hays) Kling, 1973, p. 639, pl. 5, figs. 19-21; pl. 15, fig. 6. Plate 4, Figure 1.

Lithapium mitra (Ehrenberg) Riedel and Sanfilippo, 1978, p. 69, pl. 6 , figs. 1-2.

Lithelius nautiloides Popofsky; Chen, 1975, p. 455, pl. 24, fig. 7.

Lithocyclia crux Moore; Riedel and Sanfilippo, 1978, p. 70, pl. 6, fig. 7.

Lithomelissa challengerae Chen, 1975 , p. 457 , pl. 8, fig. 3.

Lithomelissa sphaerocephalis Chen, 1975 p. 457, pl. 8, figs. 1-2.

Lithomelissa sp. C. Chen, 1975 , p. 458 , pl. 11, figs. 3-4. Plate 5, Figure 5.

Lophocyrtis biaurita (Ehrenberg) Riedel and Sanfilippo, 1978, p. 70, pl. 6, fig. 13.

Lophocorys sp. aff. L. norvegiensis Bjørklund and Kellogg, 1972.

Lychnocanoma amphitrite Foreman, 1973, p. 437, pl. 11, fig. 10; Riedel and Sanfilippo, 1978, p. 70, pl. 7, figs. 2-3.

Lychnocanoma babylonis group (Clark and Campbell) Riedel and Sanfilippo, 1970, p. 528, pl. 9, figs. 1-3.

Lychnocanoma bellum (Clark and Campbell) Riedel and Sanfilippo, 1970 , p. 529 , pl. 10, fig. 5; Foreman, 1973, p. 437, pl. 1, fig. 17; pl. 11 , fig. 9.

Lychnocanoma sp. aff. L. bellum (Clark and Campbell, 1942).

Lychnocanoma grande (Campbell and Clark) Kling, 1973, p. 637, pl. 10, figs. 11, 13-14; Weaver et al., 1981, p. 82, pl. 2, figs. 4-5.

Lychnocanoma grande rugosum (Riedel), 1952, pl. 6, fig. 1; Hays, 1965 , p. 175 , pl. 3 , fig. 5 .; Weaver 1976 a, p. 581 , pl. 9, fig. 5. Plate 2, Figure 1.

Lychnocanoma sp. aff. L. grande (Campbell and Clark, 1944).

Lychnocanoma sphaerothorax Weaver, 1976, pp. 581-582, pl. 5, figs. 4-5.

Periphaena decora Ehrenberg; Sanfilippo and Riedel, 1973, pl. 8, figs. $8-10$; pl. 27, figs. $2-5$.

Peripyramis circumtexta Haeckel, 1887, p. 54, fig. 5; Weaver, 1976a, p. 582, pl. 1, fig. 5. Plate 1, Figure 1.

Phormocyrtis embolum (Ehrenberg) Johnson, 1974, p. 548, pl. 4, fig. 5.

Phormocyrtis striata striata Brandt; Riedel and Sanfilippo, 1978, p. 71 , pl. 7, fig. 11 .

Polysolenia sp.

Prunopyle hayesi Chen, 1975, p. 454, pl. 9, figs. 3-5; Weaver, 1976a, p. 578 , pl. 7, figs. 1-3.

Prunopyle titan (Campbell and Clark) Hays (1965), p. 173, pl. 2, fig. 4; Weaver, 1976a, p. 578, pl. 7, fig. 6.

Pterocanium praetextum eucolpum Haeckel; Moore and Nigrini, 1979, pp. N43-N44, pl. 23, fig. 3.
Pterocanium trilobum (Haeckel) Moore and Nigrini, 1979, pp. N45N46, pl. 23, figs. $4 \mathrm{a}-\mathrm{c}$.

Pterocorys hirundo Haeckel, 1887, p. 1318, pl. 71, fig. 4; Riedel, 1958 , p. 238 , pl. 4 , fig. 1 ; Chen, 1975 , p. 458 , pl. 19, fig. 3.

Pterocorys zancleus (Müller) Moore and Nigrini, 1979, pp. N89-N90, pl. 25 , figs. $11 \mathrm{a}-\mathrm{b}$.

Saccospyris antarctica Haeckel; Weaver, 1976a, p. 582, pl. 1, fig. 6; Petrushevskaya, 1968, pp. 149-150, fig. 85, 11. Plate 1, Figure 4.

Saccospyris conithorax Petrushevskaya, 1965, pp. 98-99, fig. 11; 1968 , p. 150 , fig. 85,1 .

Saccospyris praeantarctica Petrushevskaya, 1975, p. 589, pl. 13, figs. 19-20. Plate 1, Figure 8.

Saturnalis circularis Haeckel; Chen, 1975, p. 454, pl. 24, fig. 2; Weaver, 1976a, p. 579, pl. 1, fig. 4. Plate 1, Figure 5.

Sethopilium macropus Haeckel; Riedel and Sanfilippo, 1977, pl. 15, fig. 11.

Siphocampe arachnea group (Ehrenberg) Nigrini, 1977, p. 255, pl. 3, figs. 7-8.

Siphocampe sp. A. Shell thick-walled, robust, consists of 4 segments of which $3 \mathrm{rd}$ or 4 th is the broadest. Cephalis approximately spherical with lateral tubule that curves slightly downward and lies along thorax. The cephalis contains numerous circular to subcircular pores. Thorax short, truncate conical, with 2-3 rows of circular pores arranged approximately in transverse rows. Lumbar and postlumbar strictures are slight. Abdomen nearly cylindrical with small circular pores arranged in 4 to 5 transverse rows. First postabdominal segment may be slightly inflated, pores circular and arranged in 3-5 transverse rows. This segment tapers distally to terminate in very distinct poreless peristome. The thoracic and abdominal pores commonly appear deepset and tilted downward. Total length, $120-135 \mu \mathrm{m}$. Length of cephalis, $11-20 \mu \mathrm{m}$; thorax, 20-25 $\mu \mathrm{m}$; abdomen, $80-90 \mu \mathrm{m}$. Maximum width, 70-80 $\mu \mathrm{m}$. Plate 4, Figure 9; Plate 6, Figure 6.

Spongothrochus glacialis Popofsky; Chen, 1975, p. 455, pl. 24, figs. 5-6.

Spongomelissa sp. Chen, 1975 , p. 458 , pl. 10, fig. 4

Spongurus pylomaticus Riedel, 1958, p. 226, pl. 1, figs. 10-11; Moore and Nigrini, 1979, pp. S65-S66, pl. 8, figs. 3a-b.

Stichocorys delmontensis (Campbell and Clark) Sanfilippo and Riedel, 1970, p. 451, pl. 1, fig. 9; Kling, 1973, p. 638, pl. 11, figs. 8-10.

Stichocorys peregrina (Riedel) Sanfilippo and Riedel, 1970, p. 451, pl. 1, fig. 10; Weaver et al., 1981, p. 83, pl. 4, figs. 1-2. Plate 6, Figures 3, 9.

Stichopilium sp.

Stylodictya validispina Jorgensen; Petrushevskaya, 1968, p. 30, pl. 17, figs. 4-5. Plate 1, Figure 9.

Stylatractus neptunus Haeckel, 1887, p. 328, pl. 17, fig. 6; Riedel, 1958 , p. 226 , pl. 1, fig. 9.

Stylatractus universus Hays, 1965, p. 167, pl. 1, fig. 6; 1970, p. 215 , pl. 1, fig. 1.

Theocalyptra bicornis Popofsky; Chen, 1975, p. 462, pl. 13, figs. 1-2.

Theocalyptra bicornis spongothorax Chen, 1975, p. 462, pl. 12, figs. $1-3$; Weaver, 1976 a, p. 582 , pl. 2, figs. $1-4$; pl. 6, figs. 2-4. Plate 5 , Figure 7.

Theocorys spongoconus Kling, 1971, p. 1087, pl. 5, fig. 6; Riedel and Sanfilippo (1978), p. 76, pl. 9, fig. 16.

Theocorys redondoensis (Campbell and Clark) Kling, 1973, p. 638, pl. 11, figs. 26-28; Weaver et al., 1981, p. 82, pl. 2, figs. 1-2. Plate 2, Figure 4.

Theocotylissa sp. aff. T. ficus (Ehrenberg, 1873).

Theocyrtis diabloensis Clark and Campbell, 1942, p. 90, fig. 13; Chen, 1975, p. 459, pl. 5, figs. 4-7.

Theocyrtis tuberosa Riedel, 1959, p. 298, pl. 2, figs. 10-11; Riedel and Sanfilippo, 1978, p. 78, pl. 1, fig. 10 . The specimens of $T$. tuberosa identified in Hole 511 are similar to the ancestral form of the species.

Tholospyris sp. A. Lattice shell crown-shaped; sagittal stricture slight. Apical spine short, often broken. Sagittal ring appears to be D-shaped; joined to front, apex, and back of the shell. Lattice shell smooth, constricted along sagittal ring; perforated by small circular to subcircular, closely spaced lattice pores. Three short bladed feet, broad and fenestrated proximally, tapering quickly, 
distally. In some specimens, lattice shell extends below base and joins proximal ends of feet. Latticework between the feet contains numerous pores of irregular size and shape. Maximum width, $85-114 \mu \mathrm{m}$; maximum length, $70-96 \mu \mathrm{m}$; length of feet, $20-33 \mu \mathrm{m}$. Plate 4, Figures 2-3.

Thyrsocyrtis sp. aff. T. bromia (Ehrenberg, 1873).

Thyrsocyrtis sp. aff. T. tetracantha (Ehrenberg, 1873).

Thyrsocyrtis sp. aff. T. triacantha (Ehrenberg, 1873).

Triceraspyris antarctica (Haeckel) Weaver (1976), p. 579, pl. 1, figs. 2-3. Plate 1, Figure 2.

Triceraspyris coronata Weaver, 1976, p. 580, pl. 2, figs. 4-5; pl. 6, figs. 8-9. Plate 2, Figures 2-3.

\section{REFERENCES}

Bandy, O. L., Casey, R. E., and Wright, R. C., 1971. Late Neogene planktonic zonation, magnetic reversals, and radiometric dates, Antarctic to the Tropics. In Reid, J. L. (Ed.), Antarctic Oceanology I. Am. Geophys. Union, Antarct. Res. Ser., 15:1-26.

Bjørklund, K. R., 1976. Radiolaria from the Norwegian Sea, Leg 38 of the Deep Sea Drilling Project. In Talwani, M., Udintsev, G., et al., Init. Repts. DSDP, 38: Washington (U.S. Govt. Printing Office), 1101-1168.

Bjørklund, K. R., and Kellogg, D. E., 1972. Five new Eocene radiolarian species from the Norwegian Sea. Micropaleontology, 18: 386-396.

Campbell, A. S., and Clark, B. L., 1944. Miocene Radiolarian Faunas from Southern California. Geol. Soc. Am. Spec. Paper 51.

Chen, P.-H. 1975. Antarctic radiolaria. In Hayes, D. E., Frakes, L. A., et al., Init. Repts. DSDP 28: Washington (U.S. Govt. Printing Office), 437-513.

Clark, B. L., and Campbell, A. S., 1942. Eocene Radiolarian Faunas from the Mt. Diablo Area, California. Geol. Soc. Am. Spec. Paper 39.

Dinkelman, M. G., 1973. Radiolarian stratigraphy: Leg 16, Deep Sea Drilling Project. In van Andel, Tj. H., Heath, G. R., et al., Init. Repts. DSDP, 16: Washington (U.S. Govt. Printing Office), 747-813.

Ehrenberg, C. G., 1844. Uber 2 neue Lager von Gebirgsmassen aus Infusorien als Meeres-Absatz in Nord-Amerika und eine Vergleichung derselben mit den organischen Kreidegebilden in Europa und Afrika, Abh. Kl. Preuss. Akad. Wiss. Berlin, p. 57.

1858. Kurze Charakteristik der 9 neuen Genera und der 105 neuen Species des Agalischen Meers und des Tiefgrundes des Mittel-Meeres. Monatsber. Kl. Preuss. Akad. Wiss. Berlin, p. 10. 1873. Grossere Felsproben des Polycystinen-Mergels von Barbados mit weiteren Erlauterungen. Monatsber. Kl. Preuss. Akad. Wiss, Berlin, p. 213.

1875. Fortsetzung der mikrogeologischen Studien als Gesammt-Uebersicht der mikroskopischen Paläontologie gleichartig analysirter Gebirgsarten der Erde, mit spezieller Rucksicht auf den Polycystinen-Mergel von Barbados. Abh. Kl. Akad. Wiss. Berlin, pp. 1-226.

Foreman, H. P., 1973. Radiolaria of Leg 10 with systematics and ranges for the families Amphipyndacidae, Artostrobiidae, and Theoperidae. In Worzel, J. L., Bryant, W., et al., Init. Repts. DSDP, 10: Washington (U.S. Govt. Printing Office), 407-474. 1975. Radiolaria from the North Pacific, Deep Sea Drilling Project, Leg 32. In Larson, R. L., Moberly, R., et al., Init. Repts. $D S D P$, 32: Washington (U.S. Govt. Printing Office), 579-676.

Haeckel, E., 1887. Report on the Scientific Results of the Voyage of H.M.S. Challenger during the Years 1873-1876. Zoology, Vol. 18. Report on the Radiolaria: London (Eyre and Spottiswoode).

Haq, B. U., et al., 1980. Late Miocene marine carbon-isotopic shift and synchroneity of some phytoplanktonic biostratigraphic events. Geology, 8:427-431.

Hays, J. D., 1965. Radiolaria and late Tertiary and Quaternary history of Antarctic seas. In Llano, G. A. (Ed.), Biology of the Antarctic Seas II. Am. Geophys. Union, Antarct. Res. Ser., 5: 125-184.

Hays, J. D., Lozano, J. A., Shackleton, N., and Irving, G., 1976. Reconstruction of the Atlantic and western Indian Ocean sectors of the 18,000 B. P. Antarctic Ocean. In Cline, R. M., and Hays, J. D. (Eds.), Investigation of Late Quaternary Paleoceanography and Paleoclimatology. Geol. Soc. Am. Mem., 145:337-372.

Hays, J. D., and Opdyke, N. D., 1967. Antarctic radiolaria, magnetic reversals, and climatic change. Science, 158:1001-1011.
Hays, J. D., and Shackleton, N., 1976. Globally synchronous extinction of the radiolarian Stylatractus universus. Geology, 4: 649-652.

Johnson, D. A., 1974. Radiolaria from the eastern Indian Ocean, DSDP Leg 22. In von der Borch, C. C., and Sclater, J. G., et al., Init. Repts. DSDP, 22: Washington (U.S. Govt. Printing Office), 521-575.

Johnson, D. A., and Wick, B. J., 1982. Precision of correlation of radiolarian datum levels in the Middle Miocene, equatorial Pacific. Micropaleontology, 28:43-58.

Keany, J., 1979. Early Pliocene radiolarian taxonomy and biostratigraphy in the Antarctic region. Micropaleontology, 25:50-74.

Kellogg, D. E., 1975. The role of phyletic change in the evolution of Pseudocubus vema Radiolaria. Paleobiology, 1:359-370.

Kling, S. A., 1971. Radiolaria, Leg 6 of the Deep Sea Drilling Project. In Fischer, A. G., Heezen, B. C., et al., Init. Repts. DSDP, 6: Washington (U.S. Govt. Printing Office), 1069-1117.

1973. Radiolaria from the eastern North Pacific, Deep Sea Drilling Project, Leg 18. In Kulm, L. D., von Huene, R., et al., Init. Repts. DSDP, 18: Washington (U.S. Govt. Printing Office), 617-671.

Ling, H. Y., 1975. Radiolaria: Leg 31 of the Deep Sea Drilling Project. In Karig. D. E., Ingle, J. C., Jr., et al., Init. Repts. DSDP, 31: Washington (U.S. Govt. Printing Office), 703-761.

Lozano, J. A., and Hays, J. D., 1976. Relationship of radiolarian assemblages to sediment types and physical oceanography in the Atlantic and western Indian Ocean sectors of the Antarctic Ocean. In Cline, R. M., and Hays, J. D. (Eds.), Investigation of Late Quaternary Paleoceanography and Paleoclimatology. Geol. Soc. Am. Mem., 145:303-336.

Martin, G. C., 1904. Radiolaria. Maryland Geol. Surv. (Miocene), Gen. Ser., pp. 447-459.

Moore, T. C. Jr., 1971. Radiolaria. In Tracey, J. I., Sutton, G. H., et al., Init. Repts. DSDP, 8: Washington (U.S. Govt. Printing Office), 727-775.

1972. Mid-Tertiary evolution of the radiolarian genus, $\mathrm{Cal}$ ocycletta. Micropaleontology, 18:244-252.

Moore, T. C., Jr., and Nigrini, C., 1979. A Guide to Modern Radiolaria. Cushman Found. Foram. Res. Spec. Publ. 16.

Nigrini, C., 1967. Radiolaria in Pelagic Sediments from the Indian and Atlantic Oceans: Berkeley and Los Angeles (Univ. California Press) Scripps Inst. Oceanogr. Bull. 11.

1977. Tropical Cenozoic Artostrobiidae (Radiolaria). Micropaleontology, 23:241-269.

Payne, R. D., 1977. Radiolaria in Brunhes sediments of the southeast Indian Ocean south of Australia [Ph.D. dissert.]. University of South Carolina, Columbia, S.C.

Petrushevskaya, M. G., 1968. Radiolarians of orders Spumellaria and Nasselaria of the Antarctic Region. In Andriiashev, A. P., and Ushakov, P. V. (Eds.), Biological Reports of the Soviet Antarctic Expedition 1955-1958 (Vol. 3): Jerusalem (Israel Program for Scientific Translations), 2-186.

1975. Cenozoic radiolarians of the Antarctic, Leg 29, DSDP. In Kennett, J. P., Houtz, R. E., et al., Init. Repts. DSDP, 29: Washington (U.S. Govt. Printing Office), 541-675.

Petrushevskaya, M. G., and Kozlova, G., 1972. Radiolaria: Leg 14, Deep Sea Drilling Project. In Hays, D. E., Pimm, A. C., et al., Init. Repts. DSDP, 14: Washington (U.S. Govt. Printing Office), 495-648.

Riedel, W. R., 1957. Radiolaria: a preliminary stratigraphy. Repts. Swedish Deep-Sea Exped. 1947-1948, 6:61-96. 1958. Radiolaria in Antarctic sediments. Repts. B.A.N.Z. Antarctic Res. Exped. Ser. B., 6:219-255. 1959. Oligocene and Miocene radiolaria in tropical Pacific sediments. Micropaleontology, 5:285-302.

Riedel, W. R., and Sanfilippo, A., 1970. Radiolaria, Leg 4, Deep Sea Drilling Project. In Bader, R. G., Gerard, R. D., et al., Init. Repts. DSDP, 4: Washington (U.S. Govt. Printing Office), 503-575. 1971. Cenozoic Radiolaria from the western tropical Pacific, Leg 7. In Winterer, E. L., Riedel, W. R., et al., Init. Repts. DSDP, 7: Washington (U.S. Govt. Printing Office), 1529-1672. 1977. Cenozoic Radiolaria. In A. T. S. Ramsey (Ed.), Oceanic Micropaleontology: New York (Academic Press), pp. 847-912.

1978. Stratigraphy and evolution of tropical Cenozoic radiolarians. Micropaleontology, 24:61-96. 
Riedel, W. R., Sanfilippo, A., and Cita, M. B., 1974. Radiolarians from the stratotype Zanclean (Lower Pliocene, Sicily). Riv. Ital. Paleont., 80:699-734.

Saito, T., Burckle, L. H., and Hays, J. D., 1975. Late Miocene to Pleistocene biostratigraphy of equatorial Pacific sediments. In Saito, T., and Burckle, L. H. (Eds.), Late Neogene Epoch Boundaries: New York (Micropaleontology Press, American Museum of Natural History), pp. 226-244.

Sanfilippo, A., and Riedel, W. R., 1970. Post-Eocene "closed" theoperid radiolarians. Micropaleontology, 16:446-462.

1973. Cenozoic radiolarians (exclusive of theoperids, artostrobiids, and amphipyndacids) from the Gulf of Mexico, Deep Sea Drilling Project Leg 10. In Worzel, J. L., Bryant, W., et al., Init. Repts. DSDP, 10: Washington (U.S. Govt. Printing Office), 475-611.

1980. A revised generic and suprageneric classification of the Artiscins (Radiolaria). J. Paleontol., 54:1008-1011.

1982. Revision of the Radiolarian genera Theocotyle, Theocotylissa, and Thyrsocyrtis. Micropaleontology, 28:170-188.

Sanfilippo, A., Burckle, L. H., Martini, E., and Riedel, W. R., 1973. Radiolarians, diatoms, silicoflagellates, and calcareous nanno- fossils in the Mediterranean Neogene. Micropaleontology, 19: 205-234.

Weaver, F. M., 1976a. Antarctic radiolaria from the southeast Pacific Basin, DSDP, Leg 35. In Hollister, C. D., Craddock, C., et al., Init. Repts. DSDP, 35: Washington (U.S. Govt. Printing Office), 569-603.

1976b. Late Miocene and Pliocene radiolarian paleobiogeography and biostratigraphy of the Southern Ocean [Ph.D. dissert.]. Florida State University, Tallahassee.

Weaver, F. M., Casey, R. E., and Perez, A. M., 1981. Stratigraphic and paleoceanographic significance of early Pliocene to middle Miocene radiolarian assemblages from northern to Baja California. The Monterey Formation and Related Siliceous Rocks of California. Soc. Econ. Paleontol. Mineral. Spec. Publ., Pacific Sec., pp. 71-86.

Zachariasse, W. J., et al., 1978. Micropaleontological counting methods and techniques - an exercise on an eight metres section of the Lower Pliocene of Capo Rossello, Sicily. Utrecht Micropaleontol. Bull., 17:81-128. 


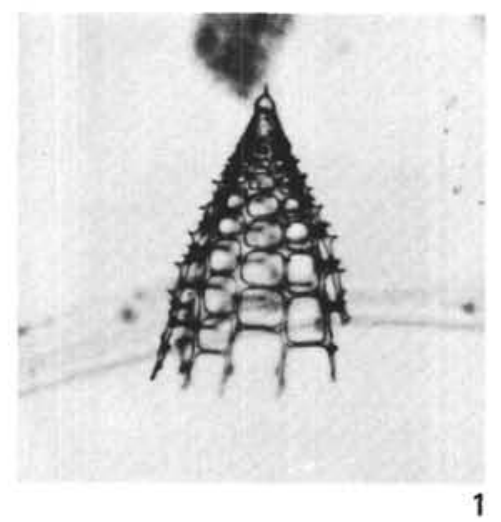

1

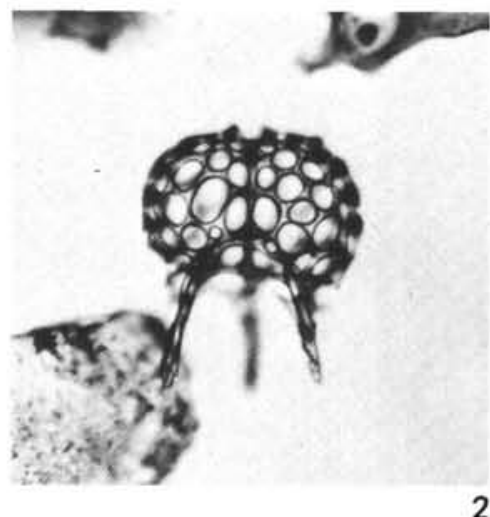

2
4
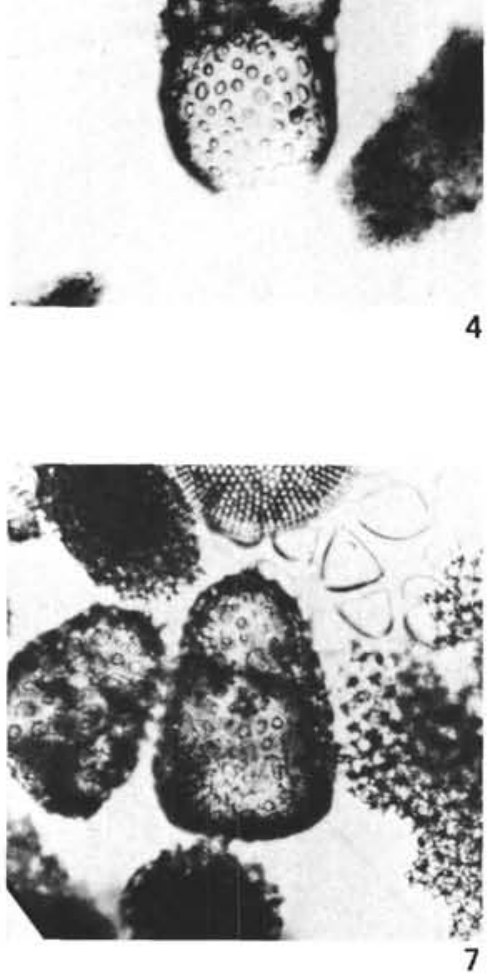
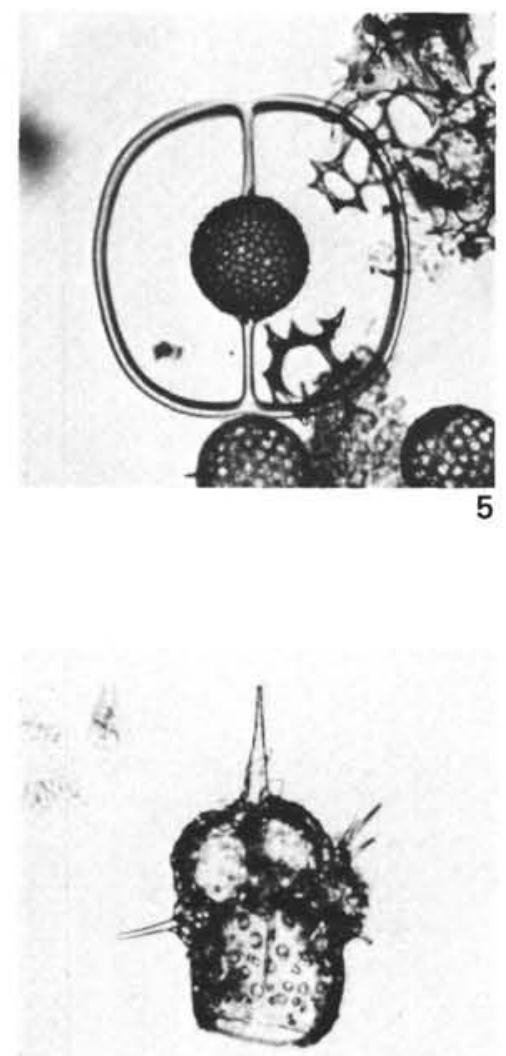

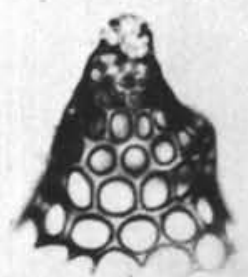

3

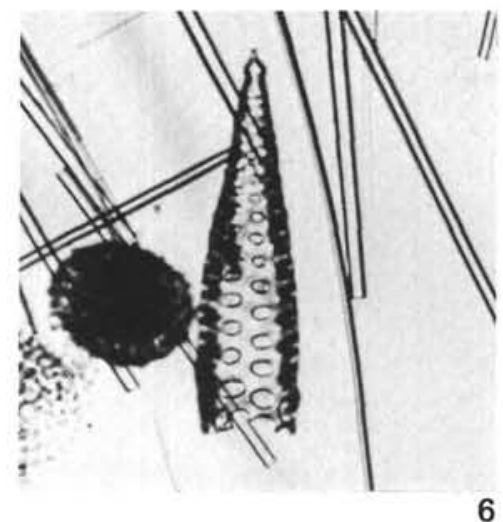

6

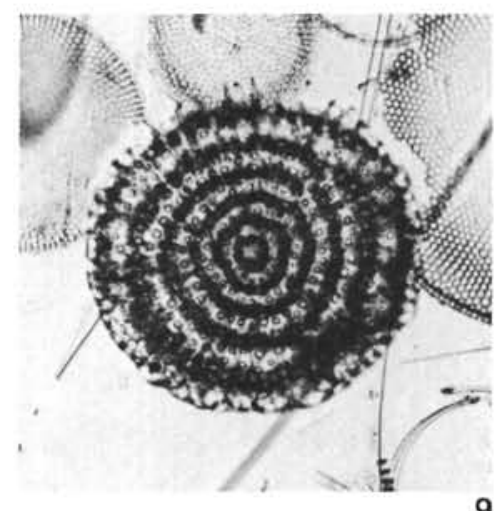

Plate 1. Cenozoic radiolarians. 1. Peripyramis circumtexta, $\times 140$, Sample $513 \mathrm{~A}-1-1,137-139 \mathrm{~cm} .2$. Triceraspyris antarctica, $\times 200$, Sample $324-1-4,68-70 \mathrm{~cm}$. 3. Cycladophora davisiana, $\times 250$, Sample 324-1-1, 143-145 cm. 4. Saccospyris antarctica, $\times 240$, Sample 324-1-1, 143$145 \mathrm{~cm}$. 5. Saturnalis circularis, $\times 160$, Sample $324-1-3,82-84 \mathrm{~cm}$. 6. Cornutella profunda, $\times 200$, Sample $513 \mathrm{~A}-1-1,137-139 \mathrm{~cm}$. 7. Antarctissa denticulata, $\times 200$, Sample 514-4,CC. 8. Saccospyris praeantarctica, $\times 280$, Sample 514-26,CC. 9. Stylodictya validispina, $\times 200$, Sample 514-26,CC. 

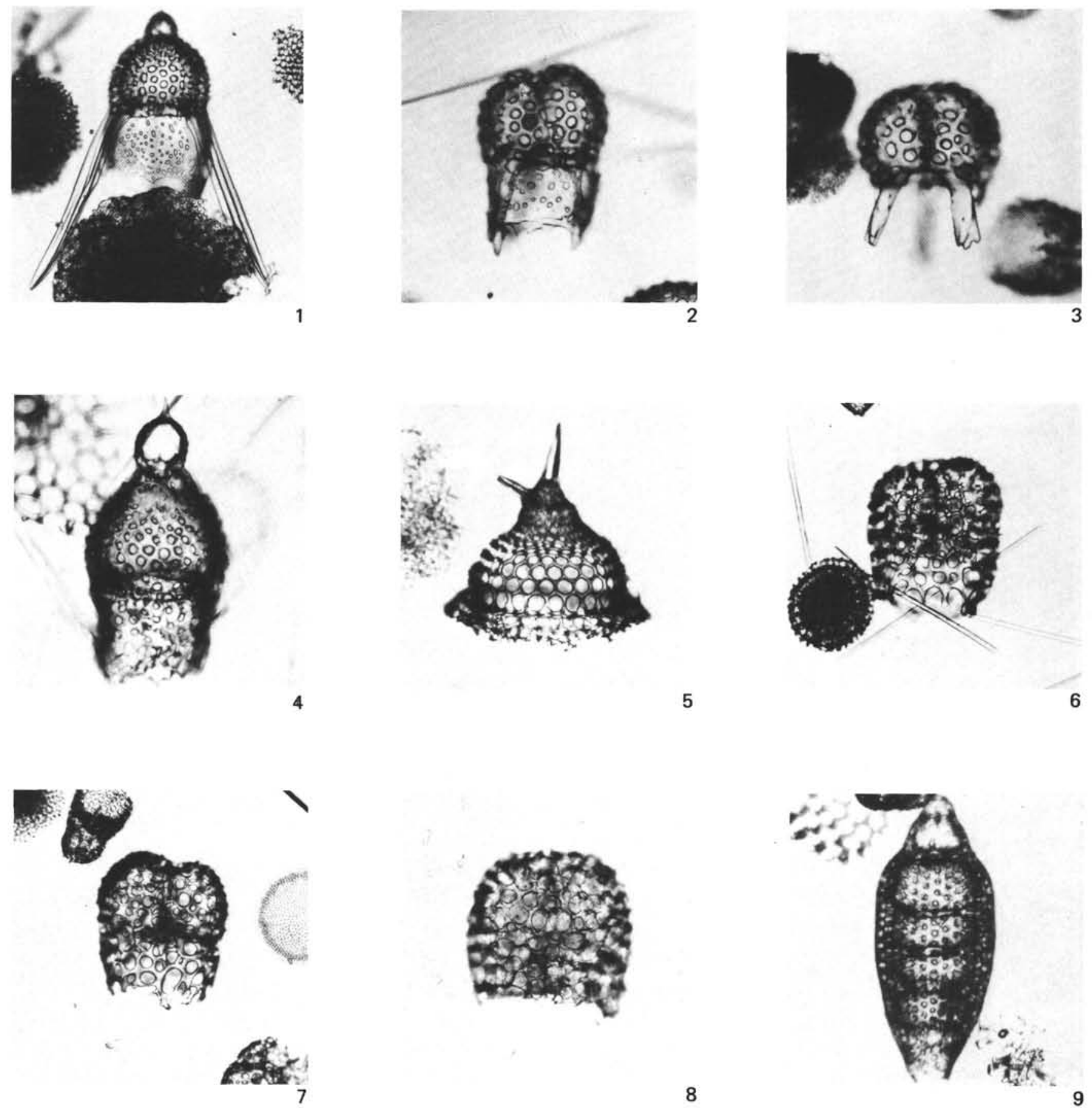

Plate 2. Cenozoic radiolarians. 1. Lychnocanoma grande rugosum, $\times 120$, Eltanin Core $38-8,460 \mathrm{~cm}$. 2-3. Triceraspyris coronata, Sample $513 \mathrm{~A}-3, \mathrm{CC},(2) \times 195,(3) \times 205$. 4. Theocorys redondoensis, $\times 270$, Sample $513 \mathrm{~A}-5-4,177-199 \mathrm{~cm}$. 5 . Clathrocyclas bicornis, $\times 200$, Sample 513A-1,CC. 6-8. Desmospyris spongiosa (6-7) $\times 170$, Eltanin Core $16-4(6,220 \mathrm{~cm} ; 7,260 \mathrm{~cm}),(8) \times 205$, Eltanin Core 38-8, 280 $\mathrm{cm}$. 9. Eucyrtidium calvertense, $\times 200$, Sample $513 \mathrm{~A}-1, \mathrm{CC}$. 

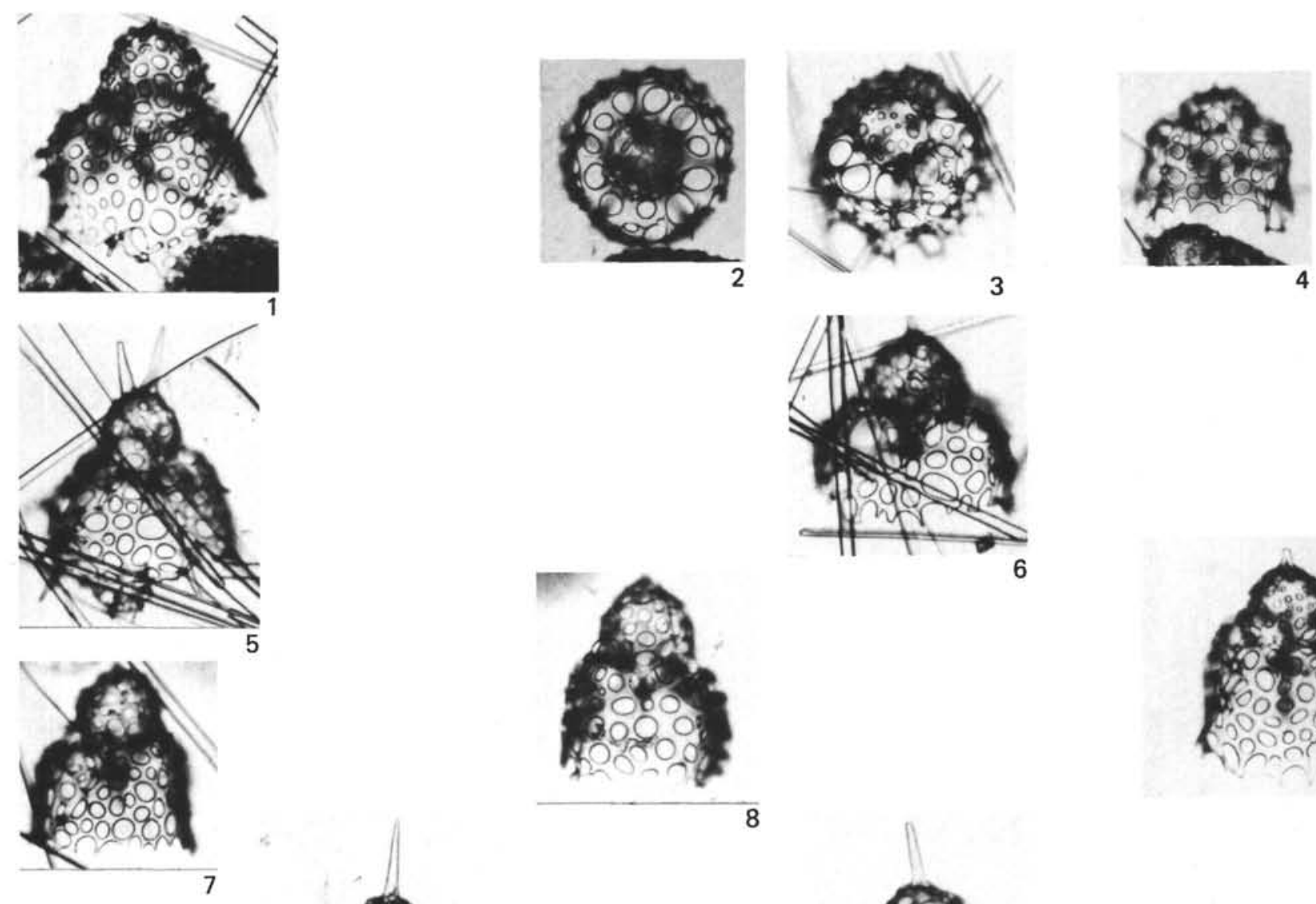

6

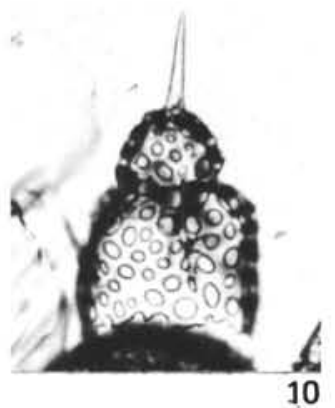

8
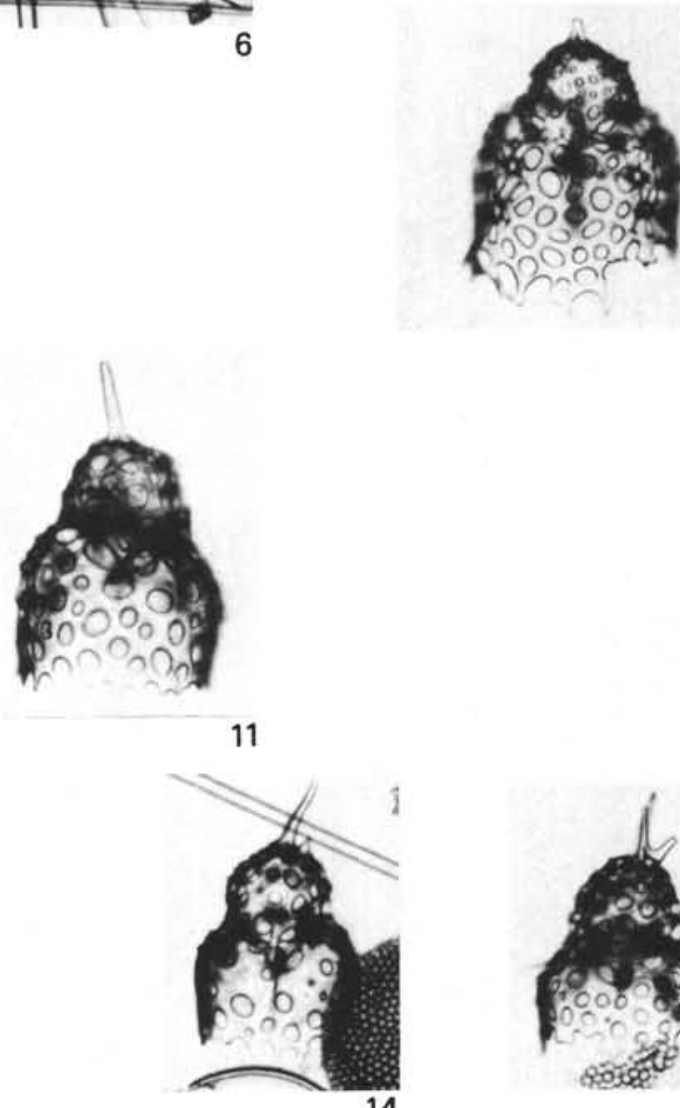

9
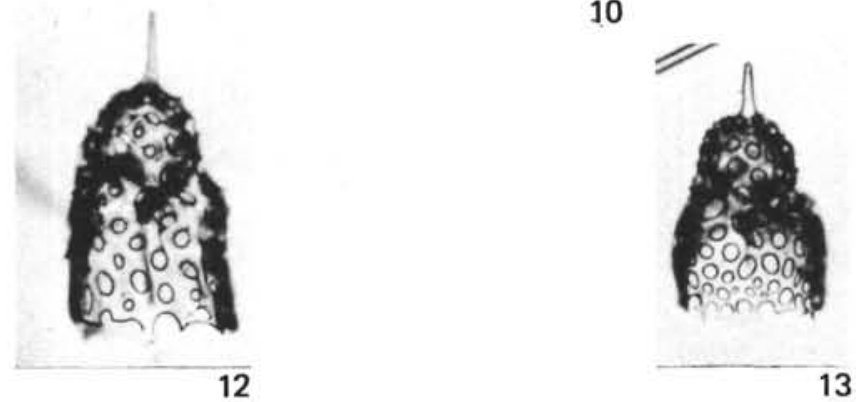

13

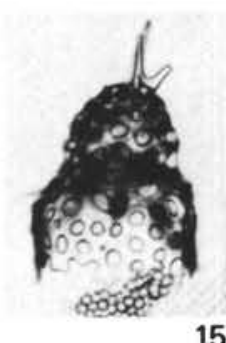

15

Plate 3. Cenozoic radiolarians. 1. Helotholus praevema n. sp., $\times 180$, Eltanin Core $50-28,380 \mathrm{~cm}$. 2-4. Helotholus vema, (2-3) Eltanin Core 50-28, $380 \mathrm{~cm} .(2, \times 155$, plan view; 3, $\times 120),(4) \times 135$, Eltanin Core 38-8, $400 \mathrm{~cm} . \quad 5-15$. Helotholus praevema, (5-7) Eltanin Core 50-28 (5, $411 \mathrm{~cm}, \times 170 ; 6,380 \mathrm{~cm}, \times 180$, transitional form; $7,300 \mathrm{~cm}, \times 170),(8-10)$ Eltanin Core $38-8(8,460 \mathrm{~cm}, \times 160 ; 9,420 \mathrm{~cm}, \times 165$, holotype; $10,460 \mathrm{~cm}, \times 170)$, (11) Eltanin Core 34-17, $580 \mathrm{~cm}, \times 175,(12-14)$ Eltanin Core $38-8(12,500 \mathrm{~cm}, \times 175 ; 13,520 \mathrm{~cm}, \times 175 ; 14,540 \mathrm{~cm}$, $\times 170),(15)$ Eltanin Core $34-17,592 \mathrm{~cm}, \times 160$. 

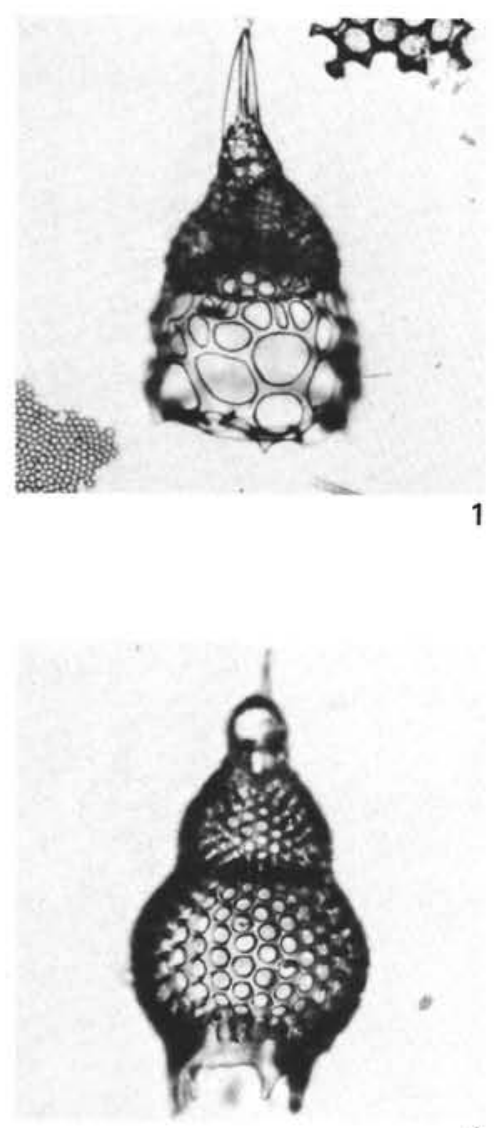

4

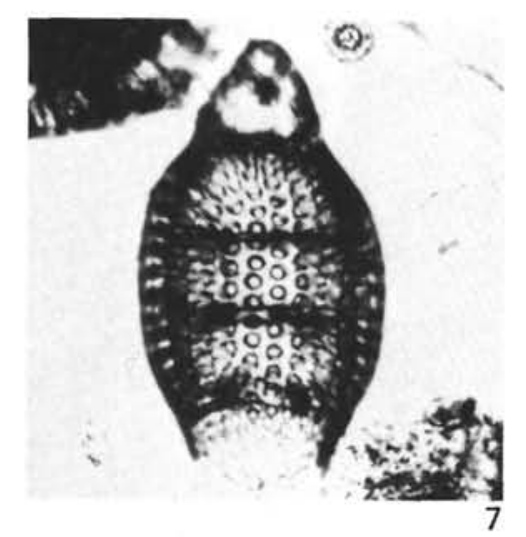

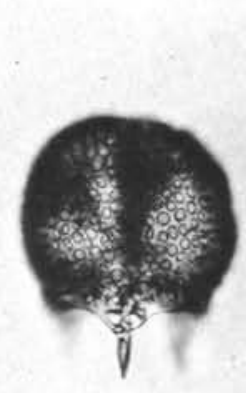

2
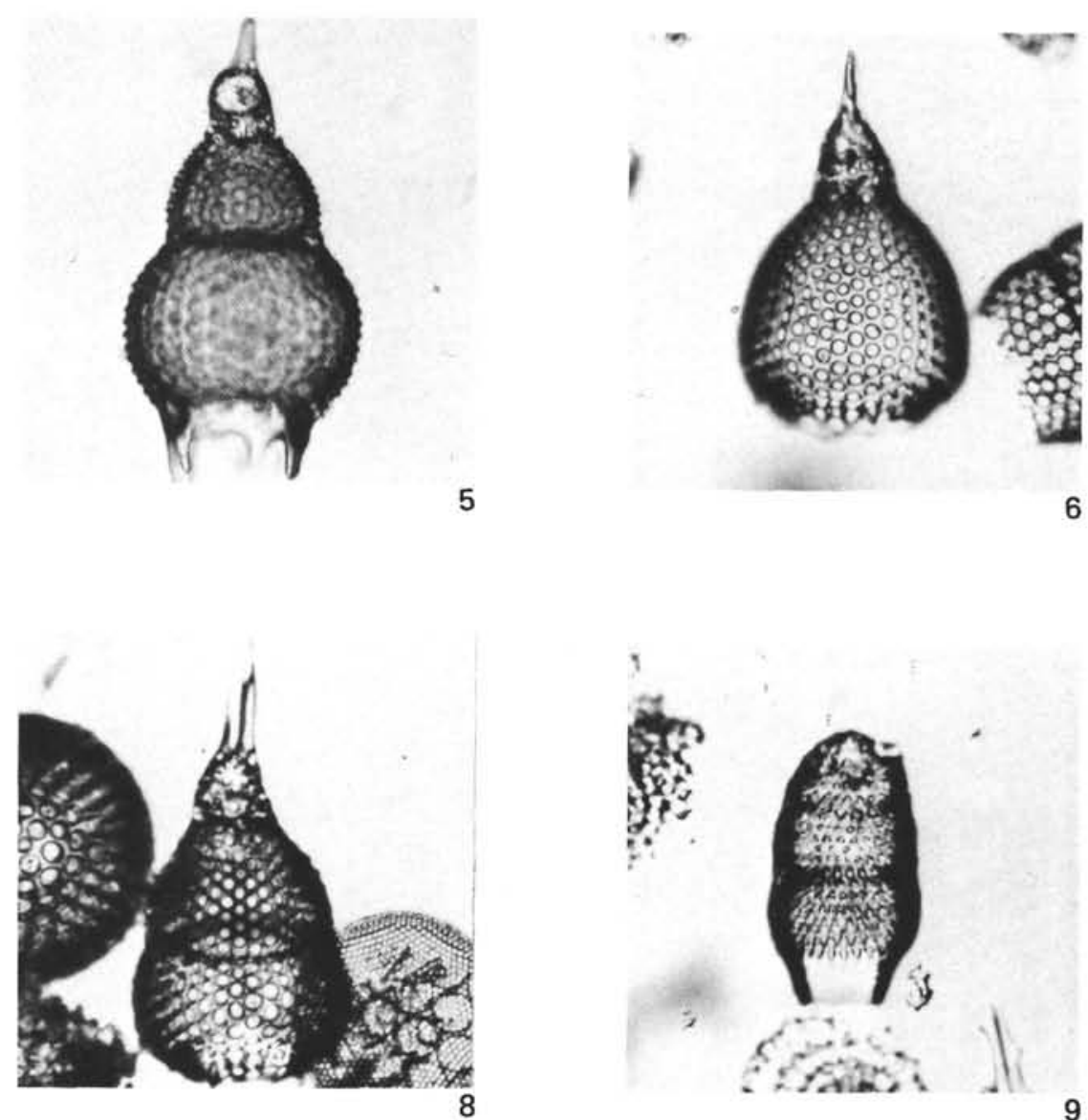

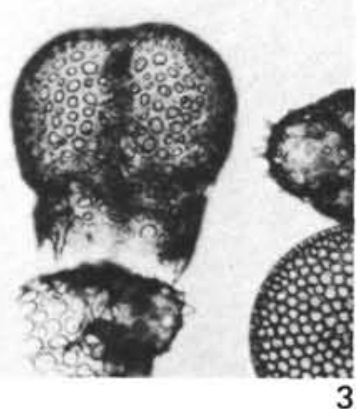

3

6

Plate 4. Cenozoic radiolarians. 1. Lamprocyrtis heteroporos, $\times 210$, Sample 514-33,CC. 2-3. Tholospyris sp. A, $\times 200$, Sample 514-33,CC. 4-5. Lamprocyclas aegles gp., $\times 170$, Sample 513A-6-7, 33-35 cm. 6. Anthocyrtidium ehrenbergii, $\times 230$, Sample 513A-7-2, 61-63 cm. 7 . Eucyrtidium calvertense $\times 240$, Sample $513 \mathrm{~A}-1$, CC. 8. Lamprocyclas maritalis, $\times 230$, Eltanin Core $39-55,691 \mathrm{~cm}$. 9. Siphocampe sp. A, $\times 210$, Sample 513A-6-5, 143-145 cm. 


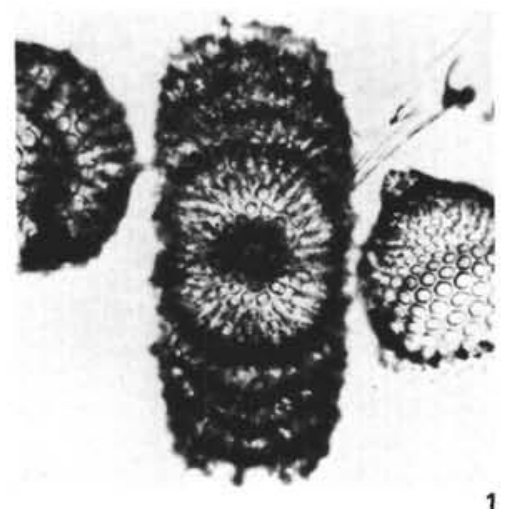

1
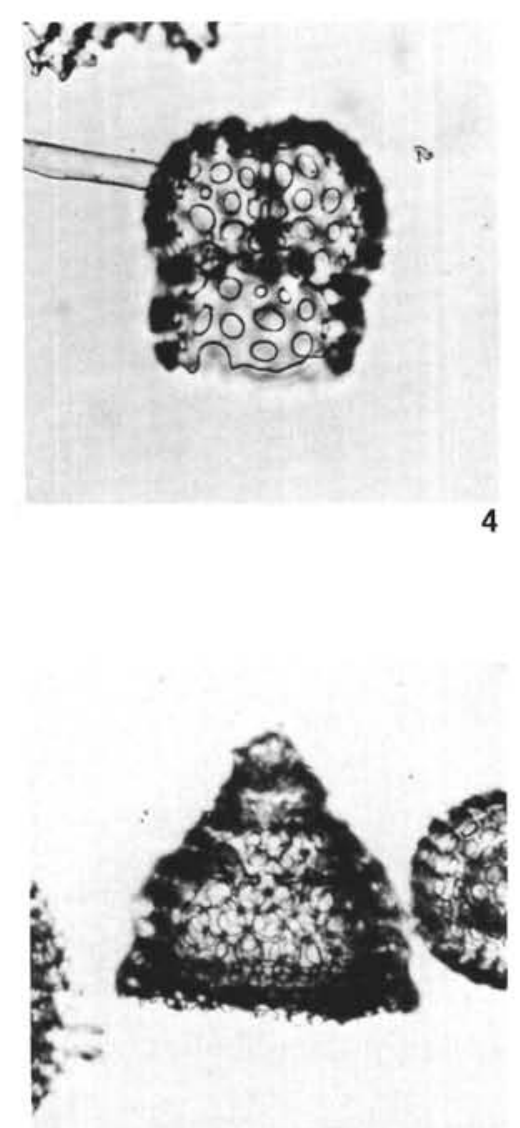

7
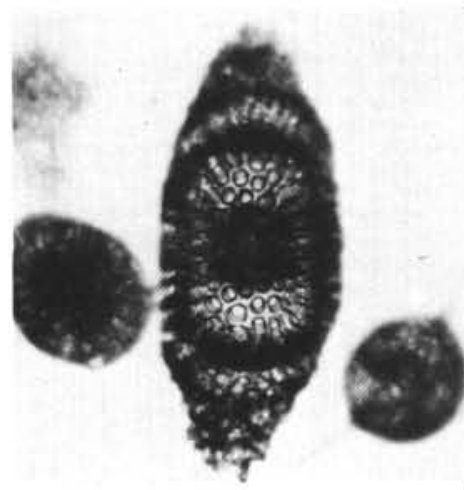

2
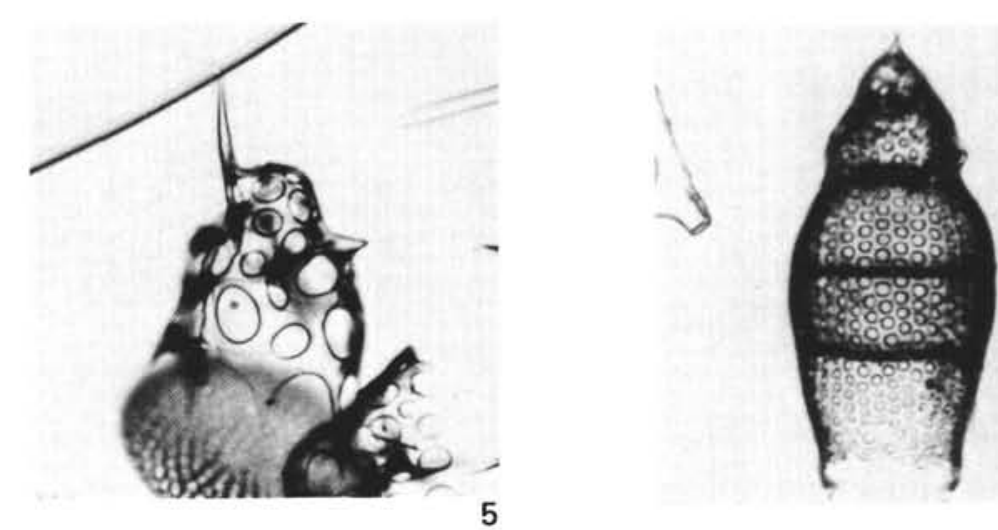

6
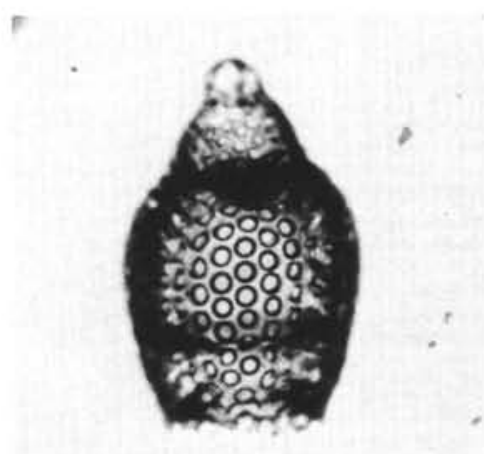

8

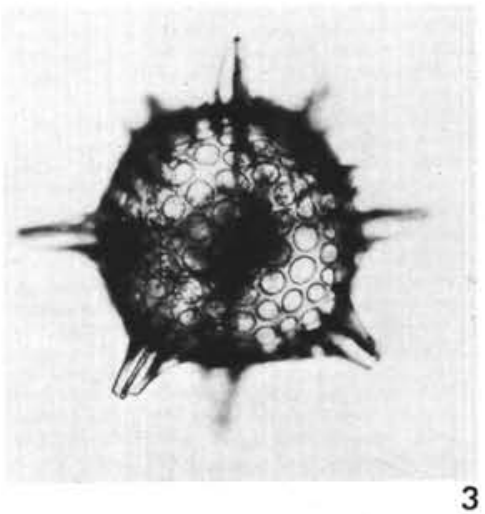

Plate 5. Cenozoic radiolarians. 1. Diartus hughesi, $\times 180$, Sample $513 \mathrm{~A}-10-5,73-75 \mathrm{~cm} . \quad 2$. Didymocyrtis antepenultimus, $\times 175$, Sample 26611-1, 60-62 cm. 3. Actinomma tanyacantha, $\times 200$, Sample $512-4-2,58-60 \mathrm{~cm}$. 4. Dendrospyris haysi, $\times 280$, Sample $512-2$, CC. 5 . Lithomelissa sp. C, $\times 260$, Sample 513A-10-4, 73-75 cm. 6. Eucyrtidium cienkowskii gp., $\times 220$, Sample 513A-7-3, 143-145 cm. 7. Theocalyptra bicornis spongothorax, $\times 250$, Sample 513A-10-4, 73-75 cm. 8-9. Eucyrtidium pseudoinflatum $\mathrm{n}$. sp., $\times 285$, Sample 278-10-5, 46-48 cm. 

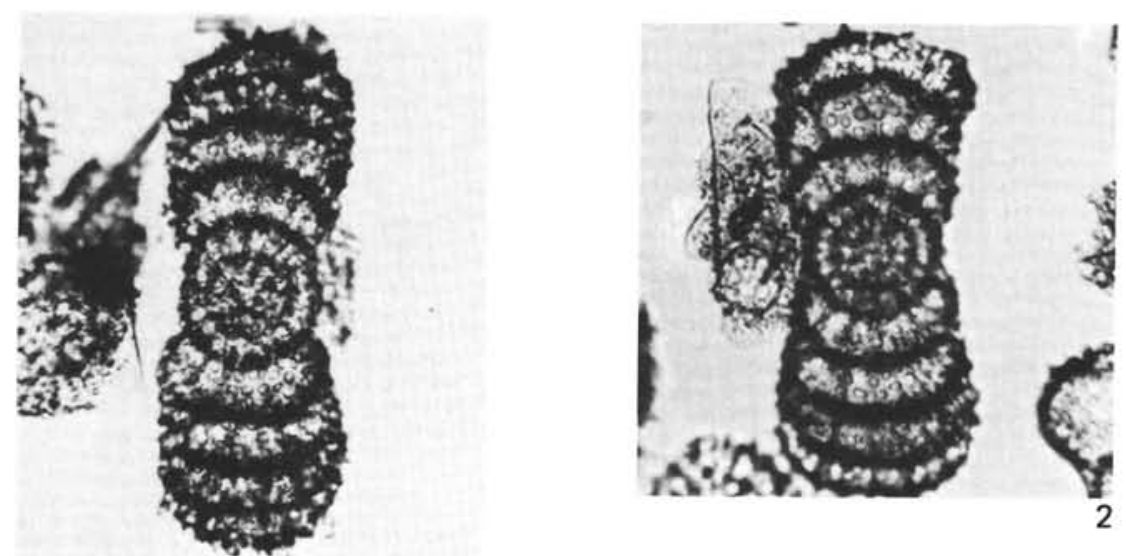

1

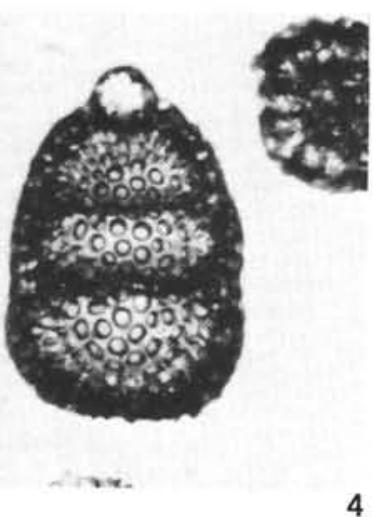

4

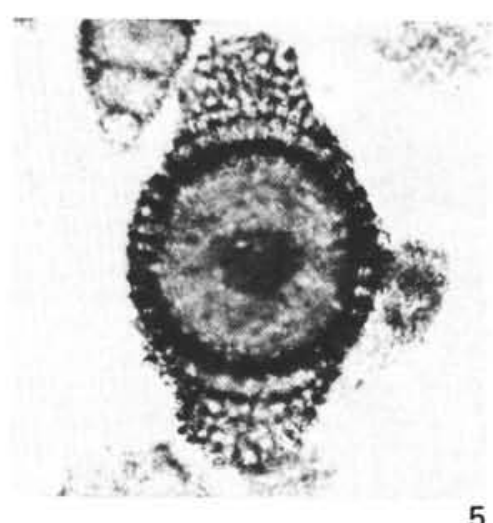

5
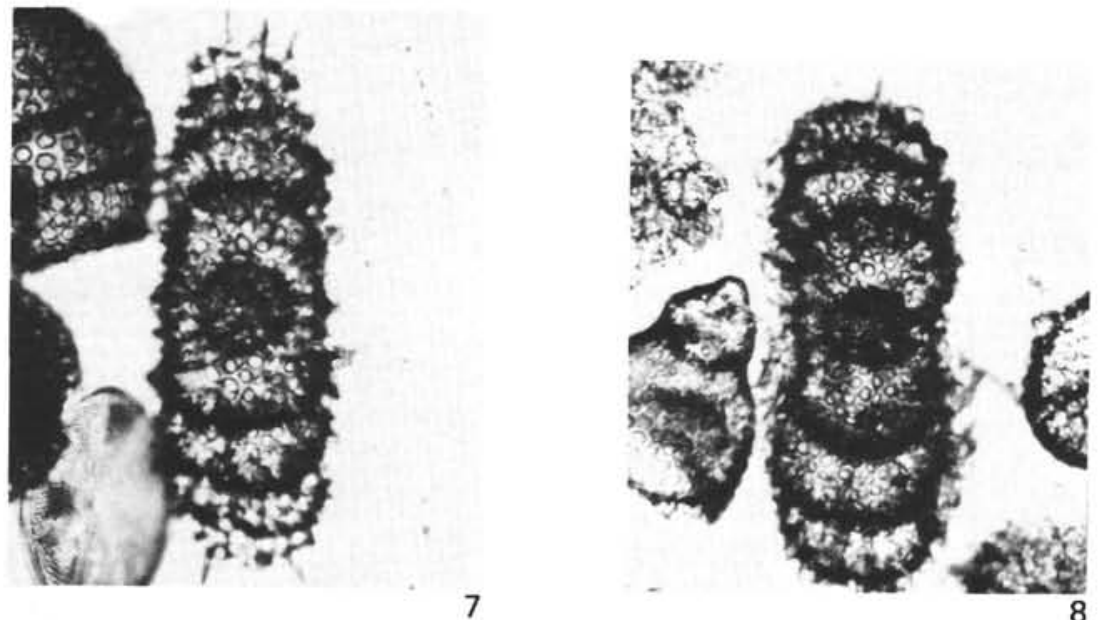

7

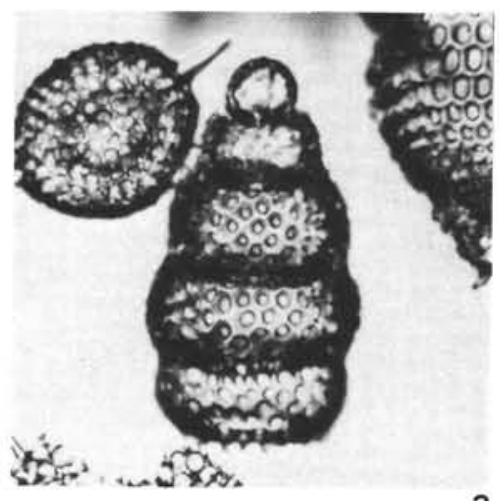

3

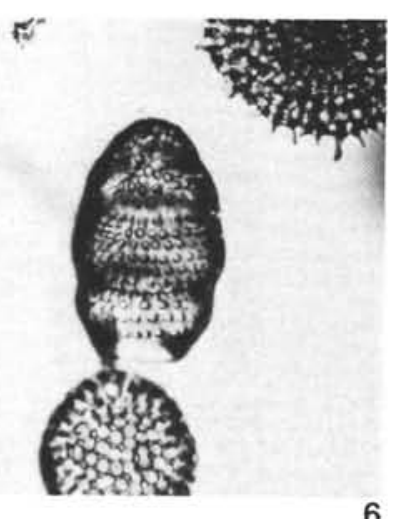

6

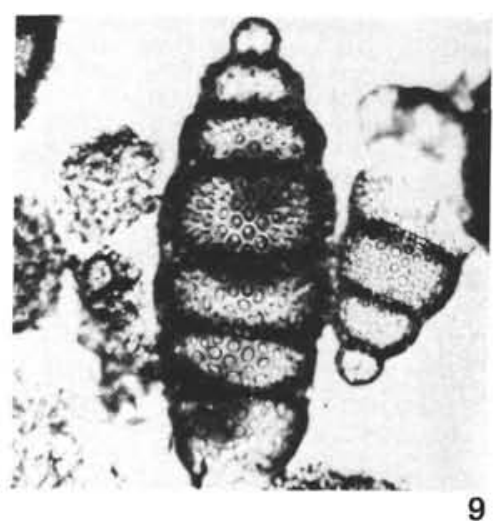

Plate 6. Cenozoic radiolarians. 1-2. Amphymenium challengerae n. sp., Sample $513 \mathrm{~A}-5-7,36-38 \mathrm{~cm}(1) \times 230$, holotype, (2) $\times 225$. 3. Stichocorys peregrina, $\times 210$, Eltanin Core 34-19, $80 \mathrm{~cm}$. 4. Cyrtocapsella tetrapera, $\times 310$, Sample $513 \mathrm{~A}-11-3,143-145 \mathrm{~cm} . \quad 5$. Didymocyrtis sp. A, $\times 160$, Sample 513A-6-7, 33-35 cm. 6. Siphocampe sp. A, $\times 215$, Sample 513A-6-5, 143-145 cm. 7-8. Didymocyrtis didymus, $\times 230$, Sample 513A-6-3, 73-75 cm. 9. Stichocorys peregrina, $\times 180$, Sample 513A-7-4, 143-145 cm. 